\title{
DE93 006985
}

SAND91 - 7037

Unlimited Release

December 1992

\section{STRUCTURES IN CONTINUOUSLY CORED, DEEP DRILL HOLES \\ AT YUCCA MOUNTAIN, NEVADA, WITH NOTES ON \\ CALCITE OCCURRENCE}

\author{
Wilfred J. Carr \\ Geologic Consultant \\ 11345 W. 38th Avenue \\ Wheat Ridge, CO 80033 \\ for \\ Sandia National Laboratories \\ P.0. Box 5800 \\ Albuquerque, NM 87185 \\ under \\ Sandia Contract $75-4358$ \\ Sandia Contract Monitor \\ Christopher A. Rautman \\ Geoscience Assessment and Validation Dept. 6115
}

\begin{abstract}
A study of more than 22,000 feet of core from five deep drill holes at Yucca Mountain, Nevada, provided data on the attitude and vertical distribution of faults and fractures, the sense of fault displacement, and the occurrence of calcite.

The study was done mainly to look for evidence of fault flattening at depth, but no consistent downward decrease in dip of faults was found, and no increase in strata rotation was evident with increasing depth. Master faults near drill holes USW G-3 and G-2, originally interpreted in reports on these holes as listric and planar, respectively, are probably geometrically more complex than originaliy assumed, and can be reinterpreted as planar and strike-slip faults.
\end{abstract}

Oblique-slip predominates on faults in core from Yucca Mountain, especially in drill hole USW G-2. Ho other particular pattern of slip is suggested by the observations, although faults with similar slip appear to cluster at various depths.

In the two drill holes located near prominent faults that dip toward the holes (USW G-3 and G-2), an apparent increase in the frequency of faults occurs below the tuffs and lavas of Calico Hills. Some of this increase occurs in brittle lavas and flow breccias in the lower part of the volcanic section. In the two holes presumed to be relatively removed from the influence of important faults at depth, the vertical distribution of faults is relatively uniform.

Calcite occurs mainly in two general zones, voids in welded portions of the Paintbrush Tuff, and in a deeper zone, mostly below 3,500 feet. Calcite is least abundant in USW G-4, which way reflect the fewer faults and fractures encountered in that drill hole.

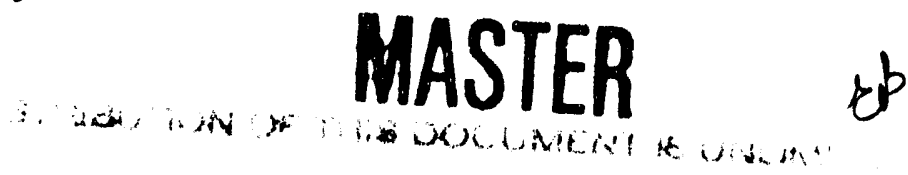


This work was performed under WBS 1.2.3.2.8.4.2.

The data in this report was developed subject to Quality Assurance controls in QAGR S123284C, Revision 1, PCA 4.0; the data is not qualified and is not to be used for licensing. 
CONTENTS

Page

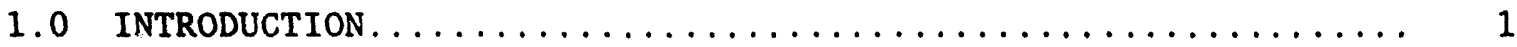

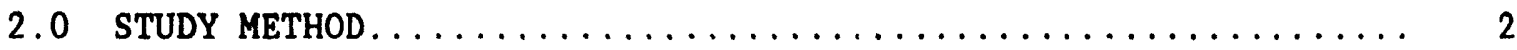

3.0 ATtITUdE OF STRUCTURAL FEATURES $\ldots \ldots \ldots \ldots \ldots \ldots \ldots \ldots \ldots \ldots$

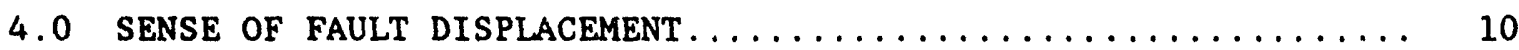

5.0 VERTICAL DISTRIBUTION OF FAULTS $\ldots \ldots \ldots \ldots \ldots \ldots \ldots \ldots \ldots \ldots$

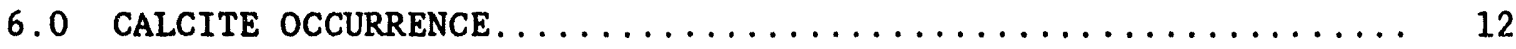

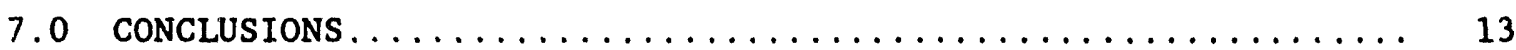

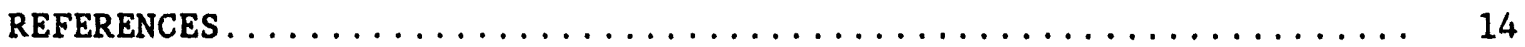

APPENDIX A SUMMARY OF FAULTS AND SELECTED FRACTURES IN DEEP CORED DRILL HOLES AT YUCCA MOUNTAIN ........... 16

APPENDIX B SECONDARY CALCITE OCCURRENCES IN CORE FROM

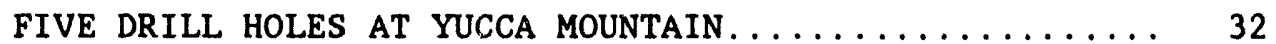

APPENDIX C INFORMATION FROM THE REFERENCE INFORMATION

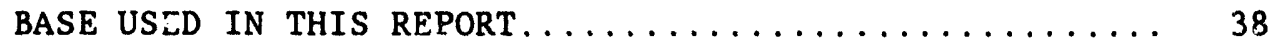




\section{LIST OF FIGURES}

Figure

Page

2-1 Index Map of Central Yucca Mountain Showing Location of Drill Holes and Faults Discussed in This Report

3-1 Relation Between Depth and Dip of Faults and strata for Drill Holes USW GU-3/G-3, G-2, and G-1

3-2 Relation Between Depth and Dip of Faults and Strata for Drill Holes USW G-4 and UE-25 a\#1

3-3 Map and Cross Section Through Drill Hole USW G-3/GU-3 Adapted From Scott and Castellanos (1984, Figures 30 and 31)

\section{LIST OF TABLES}

Table

Page

3-1 Average nip of Faults in Core From Drill Holes USW G-1, 4 $\mathrm{G}-2$, and $\mathrm{GU}-3 / \mathrm{G}-3,1,000$ Foot Intervals

4-1 Sense of Displacement from Slickensides on Faults in Deep 10 Drill Holes at Yucca Mountain 


\subsection{INTRODUCTION}

A review of U.S. Geological Survey reports on five continuously cored drill holes at Yucca Mountain indicates that few data have been published on the distribution and dips of faults encountered in these holes. Such information could constitute evidence bearing upon the mechanism and timing of faults in the proposed repository site area. The variation in frequency of faults with depth also might be considered as evidence of the mechanism and chronology of structural development of Yucca Mountain. Information on the style and chronology of faulting is important in development of a tectonic model, which in turn may be used to predict future fault movements and the degree of long-term structural and hydrologic stability of the Yucca Mountain area.

The extensional structure at Yucca Mountain consists mainly of a series of nearly parallel normal faults that strike north to north-northeast. At the surface the large faults are spaced about $1 / 2$ to $1 \mathrm{mile}$ apart and dip steeply west at $65^{\circ}$ to $80^{\circ}$ (Scott and Bonk, 1984). The tuffs they displace dip eastward at $5^{\circ}$ to $15^{\circ}$.

The subsurface configuration of the faulting has not been well-defined by existing drill holes. The faults may be listric, planar, or both. It has been suggested, principally by Scott (1990), that Yucca Mountain is underlain by westward-dipping, low-angle normal or detachment faults. In such a model, many faults of the upper plate of the decachment are 1istric or curviplanar and flatten toward low-angle faults at depth. If this is the case, fault inclination should show, on average, a gradual decline with increasing drill hole depth. According to Scott (1990), an accommodation structure, probably a low-angle normal fault, should occur between 1 and 4 kilometers $(3,200$ to 13,000 feet); several of the drill holes at Yucca Mountain reach depths of 6,000 feet. In addition, structural rotation of strata could increase at deeper levels if the faults flatten with depth. This could occur as a result of reverse drag flexing (Hamblin, 1965) and the tendency for strata to maintain a $90^{\circ}$ relationship with faults displacing them (Anderson, 1971). Reverse drag does not appear to be common on man; normal faults, however, suggesting that most faults are not concave surfaces, or that the curvature is slight or is restricted to deep portions of the faults (Zoback and others, 1981).

Planar or "domino-style" extensional faults require some means of accommodating the theoretical voids that would be created at the bottoms of tilted blocks. This can be accomplished by ductile flow (Miller and others, 1983), a detachment (Wernicke and Burchfiel, 1982), or by internal small-scale block deformation (Angelier and Colletta, 1983). Such deformation, if present, probably does not occur at depths penetrated by drill holes at Yucca Mountain. 


\subsection{STUDY METHOD}

All available core, approximately 22,000 feet from five drill holes (Figure 2-1), was examined at the Yucca Mountain Project Sample Management Facility at various times between November 1989 and September 1990. Faults and prominent fractures were noted and, where obvious, dips and the general orientation of slickensides were recorded. A few faults overlooked in this examination, but recorded by previous workers in published reports (Scott and Castellanos, 1984; Maldonado and Koether, 1983; Spengler et al., 1979; Spengler and Chornack, 1984; Spengler et al., 1981), were added to the data. Distinct stratal inclinations also were noted; these were combined with dips published in the above reports.

Because of the general interest of project scientists in the distribution of carbonate in the subsurface, prominent calcite coatings or void fillings were recorded during the fault examination.

The distinction between the terms "fault," "fracture," or "shear fracture," as used by some authors (e.g., Spengler and Chornack, 1984), is commonly difficult and somewhat subjective. In general, in this study a satural break in the core was called a fault if it had one or more of the following characteristics: juxtaposition of obviously different lithologies, easily identifiable slickensides, breccia or gouge, and/or unusually broken and clayey or altered rock. Only prominent, generally planar, natural fractures whose dips could be determined were recorded (Appendix $A$ ), on the assumption that most of these are related to the fault pattern; some may have slight but undetected displacement.

Drill-hole deviation from vertical has a significant effect on the structural data in two of the five drill holes, USW G-3 and USW G-2. Both holes deviated in a west-southwest direction (Scott and Castellanos, 1984, Figure 23). USW G-3 slanted westward as much as $20^{\circ}$ from the vertical (Scott and Castellanos, 1984, Figure 31). USW G-2 deviated westward almost $5^{\circ}$ from the vertical (Maldonado and Koether, 1983, Figure 3) below about 4,200 feet. In this report, correction for drill-hole deviation was based on the assumption that all faults dip westward in the deviated portions of these two drill holes, in accordance with the general structural pattern at the surface at Yucca Mountain. Therefore, the fault dips reported in Appendix A were reduced from $5^{\circ}$ to $20^{\circ}$ in the deeper portions of USW G-3, and $5^{\circ}$ in the lower part of USW G-2. Although antithetic or conjugate faults may be present locally, the mapping and cross sections by Scott and Bonk (1984) indicate faults of easterly dip are rare. 


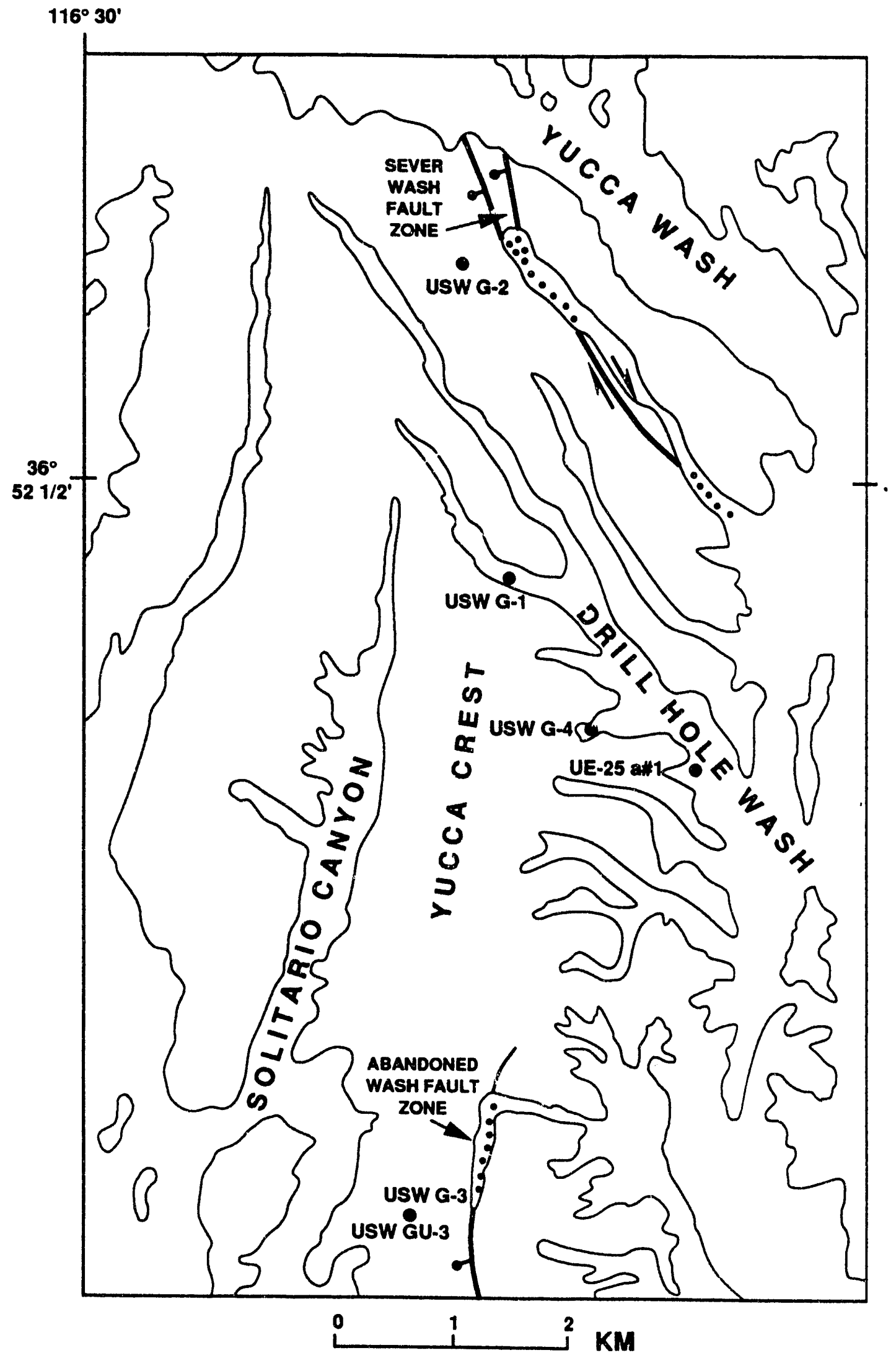

Figure 2-1. Index Map of Central Yucca Mountain Showing Location of $2: \leq 11$ Holes and Faults Discussed in This Report 


\subsection{ATTITUDE OF STRUCTURAL FEATURES}

No consistent downward decrease in dip of faults was found in this study (Figures 3-1 and 3-2), except possibly in drill hole USW G-3. If anything, there is a slight steepening of fault dips in holes USW G-1 and G-2 with increased depth (Figure 3-1). Not enough good data can be obtained from existing core to resolve structural questions at the USW G-3 drill hole, but there is no evidence that faults become lower angle with depth in the other four drill holes studied. Neither USW G-4 nor UE-25 a\#1 are deep enough to provide conclusive data, however. Data from the remaining two holes, USW G-1 and G-2, suggest a planar system of faults (Table 3-1).

Table 3-1

AVERAGE DIP OF FAULTS IN CORE FROM DRILL HOLES USW G-1, G-2, AND GU-3/G-3, 1,000 FOOT INTERVALS

Number of observations and average dip per interval

Depth, ft

USW G-1

USW G-2

USW GU - 3/G-3

\begin{tabular}{|c|c|c|c|c|c|c|}
\hline $\begin{array}{r}0-1,000 \\
1,000-2,000 \\
2,000-3,000 \\
3,000-4,000 \\
4,000-5,000 \\
5,000-6,000\end{array}$ & $\begin{array}{r}(2) \\
(5) \\
(3) \\
(31) \\
(6) \\
(8)\end{array}$ & $\begin{array}{l}50^{\circ} \\
54^{\circ} \\
48^{\circ} \\
54^{\circ} \\
60^{\circ} \\
58^{\circ}\end{array}$ & $\begin{array}{r}(9) \\
(19) \\
(7) \\
(32) \\
(55) \\
(32)\end{array}$ & $\begin{array}{l}52^{\circ} \\
65^{\circ} \\
59^{\circ} \\
53^{\circ} \\
52^{\circ} \\
55^{\circ}\end{array}$ & $\begin{array}{r}(5) \\
(3) \\
(30) \\
(6) \\
(23) \\
\text { No }\end{array}$ & $\begin{array}{l}68^{\circ} \\
50^{\circ} \\
58^{\circ} \\
62^{\circ} \\
40^{\circ} \\
\text { lata }\end{array}$ \\
\hline
\end{tabular}

\section{Structure at USW G-3}

It has been proposed (Scott and Castellanos, 1984) that faults encountered at about $1,310 \mathrm{~m}(4,297.5 \mathrm{feet})$ and $1,402 \mathrm{~m}(4,600 \mathrm{feet})$ in USW G-3 are strands of the Abandoned Wash fault zone (Figures $2-1$ and $3-3$ ) that have flattened from $77^{\circ}$ at the surface to about $50^{\circ}$ (corrected for hole deviation) at depth. Although the available information permits this interpretation, several considerations suggest that the two previously mentioned faults are not the Abandoned Wash. If so, an essentially planar Abandoned Wash fault is a reasonable alternative interpretation.

The two main faults in the drill hole occur in the Lithic Ridge Tuff, which is about 920 feet thick in USW G-3 (Scott and Castellanos, 1984, Table 10). It is about 975 feet thick in USW G-1 (Spengler et al. 1981) about 3.5 miles to the north. The Abandoned Wash Fault has about 150 feet of displacement in the vicinity of USW G-3, but despite the presence of at least 23 faults in the Lithic Ridge in USW G-3, the unit does not appear to be significantly thinned as a result of the faults, assuming the thickness at USW G-1 is representative. The faults in the Lithic Ridge in USW G-3 at depths of $4,297.5$ and 4,600 feet were described by Scott and Castellanso (1984) as "major" and containing "thick gouge zones." Examination of these structures for this report showed crushed zones 2 to 6 inches wide, but identical lithology on opposite sides of the faults. 


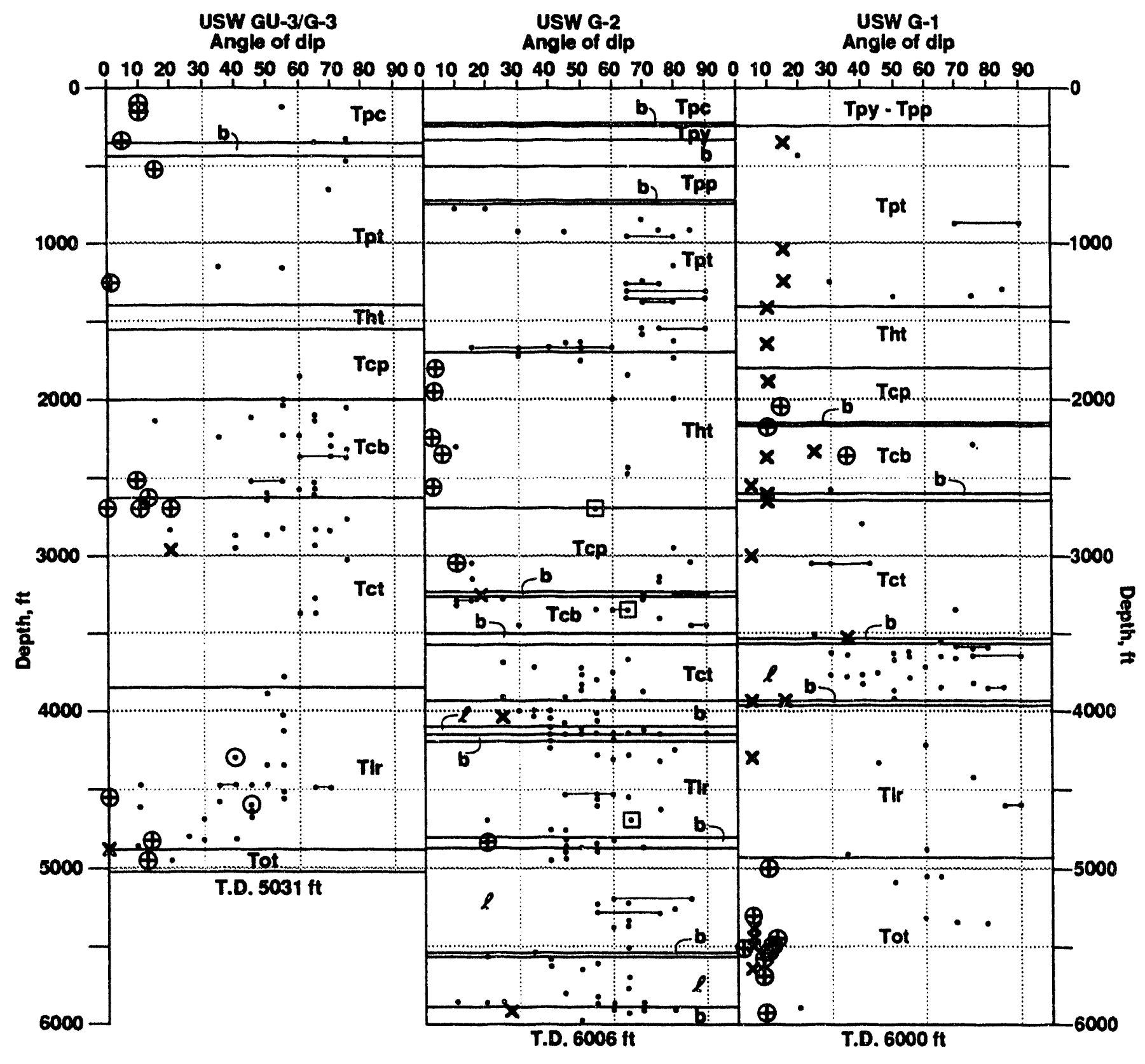

EXPLANATION

- Fault, plotted to nearest $5^{\circ}$. In a few places, faults (from Appendix A) Stratigraphic units:

of similar dip are too close together to plot separately.

[. "Important" fault of Matdonado and Koether (1983).

○ "Major" fault of Scott and Castellanos (1984).

X Stratal dip, corrected for deviation of drill holes USW G-2 and G-3.

$\oplus$ Stratal dip previously published. (See appropriate drill hole report.)

Fauth dips are corrected as follows: USW GU-3/G-3, 0-820 tt: $0^{\circ}$;

820-2460 ft: $-5^{\circ} ; 2460-3280 \mathrm{ft:}-10^{\circ} ; 3280-4100 \mathrm{ft}:-15^{\circ}$;

4100-5031 th: $-20^{\circ}$. USW G-2, 0.4200 ft: $0^{\circ} ; 4200-6006 \mathrm{ht}:-5^{\circ}$.

Tpc - Paintbrush Tuff, Tiva Canyon Member

Tpy - Paintbrush Tuff, Yucca Mountain Member

Tpp-Paintbrush Tutf, Pah Canyon Member

Tpt - Paintbrush Tuff, Topopah Spring Member

Tht - Tutfs of Calico Hills

TcP - Crater Flat Tuft, Prow Pass Member

Tcb - Crater Flat Tuff, Bulfrog Member

Tct - Crater Flat Tuff, Tram Member

Tir - Lithic Ridge Tuft

Tot - "Older" Tuffs

b Bedded tufts (Very thin units not shown)

l. Lavas and flow breccia

Figure 3-1. Relation Between Depth and Dip of Faults and Strata for Drill Holes USW GU-3/G-3, G-2, and G-1 


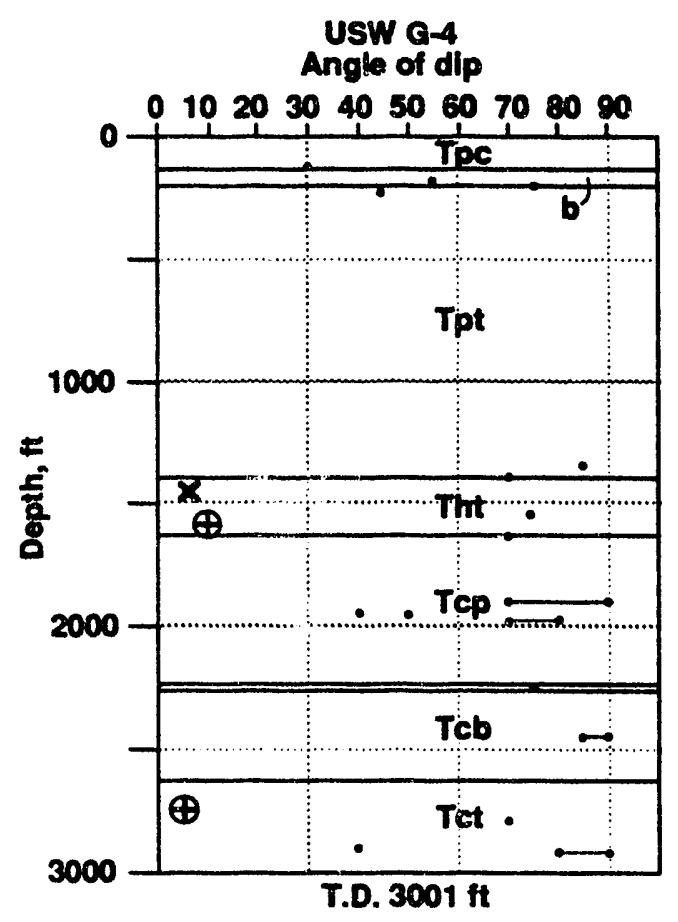

UE-25 a"1 1

Angle of dip

$0102030405060 \quad 708080$

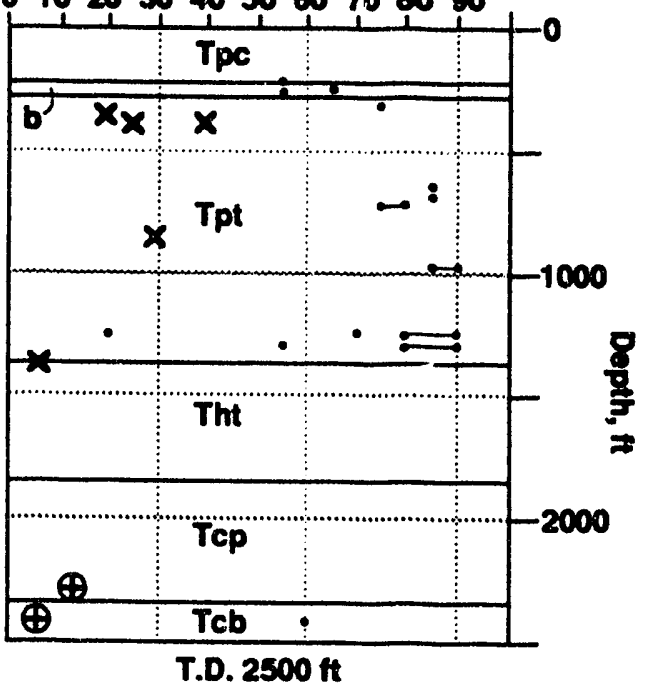

Figure 3-2. Relation Between Depth and Dip of Faults and Strata for Drill Holes USW G-4 and UE- 25 a\#1 

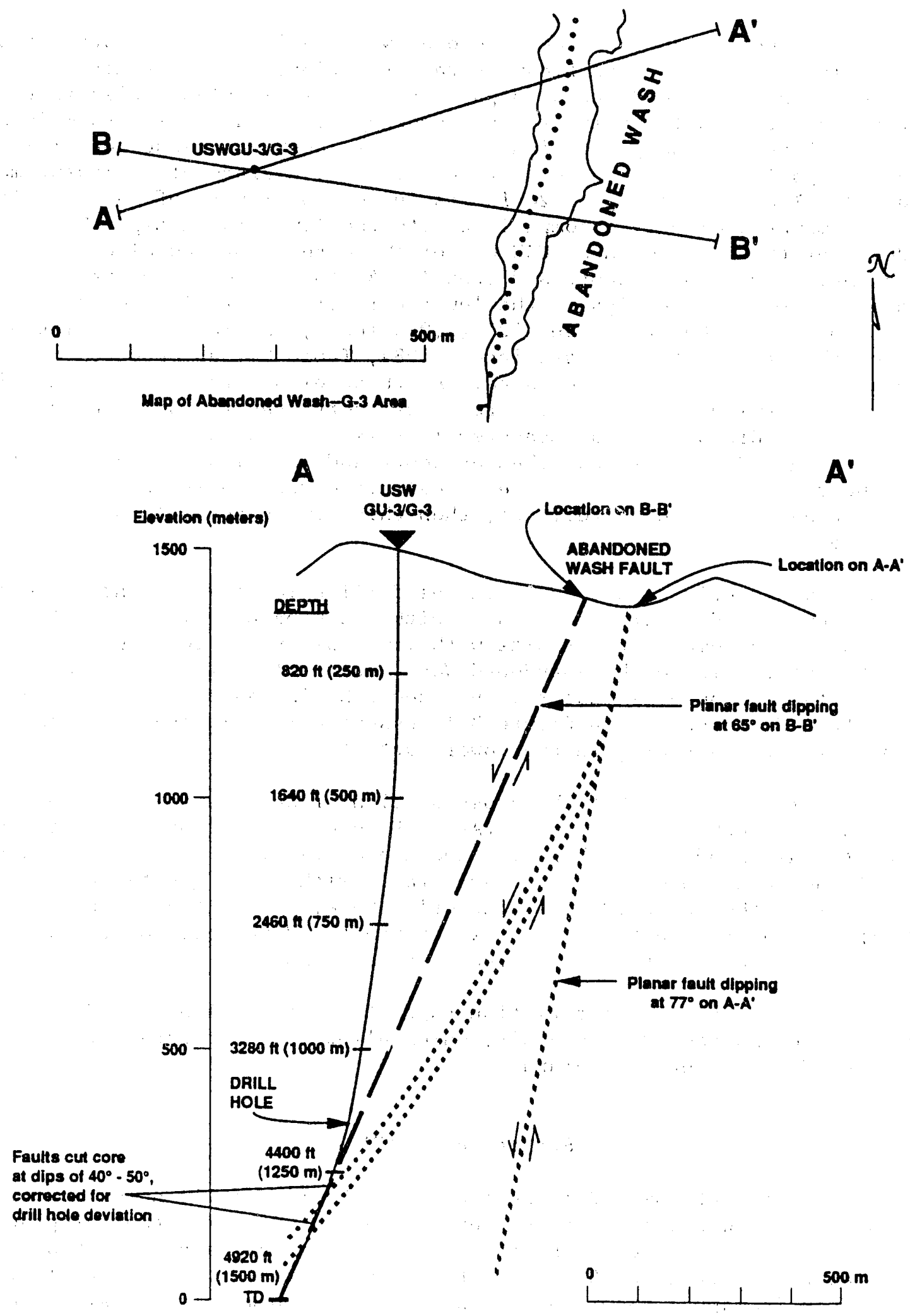

Figure 3-3. Map and Cross Section Through Drill Hole USW G-3/GU-3 Adapted From Scott and Castellanos (1984, Figures 30 and 31). Short dashed lines are fault projections from Scott and Castellanos (1984), on their cross section line A-A'. Long-dashed line is a planar abandoned wash fault dipping $65^{\circ}$ and located on a line of section ( $b-b^{\prime}$ ) at right angles to the fault. 
Another indication that the Abandoned Wash faults do not flatten toward USW G-3 is the lack of significant strata rotation. If the faults are listric one would expect the beds to be dipping at relatively high angles in the lower part of the drill hole, owing to the tendency for stratal dips to maintain a general $90^{\circ}$ relationship with faults that displace them (Anderson, 1971). No stratal dips in USW GU-3 and G-3 exceed $20^{\circ}$; the average of 16 measurements is about $8^{\circ}$. The average dip of 24 faults in the lower part of the hole is about $41^{\circ}$, an amount seemingly incompatible with the low stratal dip. There is no evidence of the presence near USW G-3 of the highly rotated blocks of Tiva Canyon Member mapped by Scott and Bonk (1984) to the north on the west side of Abandoned Wash. Three dips in the lower part of the drill hole are $0^{\circ}(4,560$ feet), and $13^{\circ}(4,890$ feet $)$ and $12^{\circ}(4,964$ feet); the latter two dips are west-northwest (Scott and Castellanos, 1984, Table 9), as opposed to the generally eastward dips of the area. As these dips were measured on oriented core it is assumed that they are true dips, corrected for drill-hole deviation. A dip of $20^{\circ}$ was measured in this study at a depth of 4,874 feet, but it is in bedded tuff described by Scott and Castellanos (1984, p. 121) as cross bedded and reworked. If the actual dip direction is westerly, as indicated by Scott and Castellanos, then this dip is actually nearly horizontal, as plotted in Figure 3-1.

The low westerly strat i dips in the drill hole at 4,560 and 4,890 fett could be explained as dra sociated with the hanging wall of the Abandoned Wash Fault, and some of the fallts with low dips in the lower part of the hole could be antithetic to the Abandoned Wash Fault. If this is correct, the dip of these faults would be easterly and should be increased about $15^{\circ}$ to $20^{\circ}$, rather than decreased as in Figure 3-1, essentially removing the apparent trend of fault flatiening in the lower part of USW G-3.

It should be noted that the cross section of Scott and Castellanos (1984, Figure 31) through the drill hole (A-A', Figure 3-3) is not drawn at right angles to the Abandoned Wash Fault, and therefore gives a somewhat distorted view of the relationships. Any planar fault with a dip greater than $65^{\circ}$ will not intersect the westward deviating drill hole, but if the fault is listric and dips $77^{\circ}$ at the surface, as shown by Scott and Castellanos (1984, Figure 31 ), a more abrupt flattening is required than shown.

In summary, existing information suggests that drill hole USW G-3 did not encounter the Abandoned Wash Fault, which allows the interpretation that the fault could be essentially planar.

\section{Structure at USW G-2}

The structue at USW G-2 is unique among the five drill holes studied. Together with USW G-3 it contains several faults with important displacement, but of more significance is the fact that it lies near a northwest-striking right-lateral fault zone (Scott and Bonk, 1984), the Sever Wash Fault (Figure $2-1$ ). This is mapped (Scott and Bonk, 1984) as two main subparallel faults that dip toward the drill hole. According to Maldonado and Koether (1983, Figure 22), two strands of the fault were penetrated at depths of 2,704 and 4,672 feet in USW G-2; dips of about $55^{\circ}$ and $65^{\circ}$, repsectively, were measured in this study, in agreeent with those reported by Maldonado and Koether (1983). They projected these dips to the surface as planar faults that appear to coincide with the location of the two Sever Wash fault strands, but 
surface dips measured (Scott and Bonk, 1984) on the westernmost of the two faults are significantly high. than the subsurface drill hole dip of $55^{\circ}$. Six surface dips of the western fault range form $74^{\circ}$ to $87^{\circ}$, and average $80^{\circ}$. Thus, an unrealistically abrupt flattening from $80^{\circ}$ at the surface to $55^{\circ}$ at 2,704 feet would be required if the faults connect.

Unlike the other deep drill holes, USW G-2 shows a distinct and persistently greater number of faults at depth, below the tuffs of Calico Hills (Figure 3-1; Table 3-1). Between the top of the Crater Flat Tuff (the fault at 2,704 feet) and the bot $m$ of the hole at 6,006 feet, more than 166 faults were noted. Most of these faults show oblique or horizontal slip (Table 4-1). No such swarm of faults is evident at the surface; therefore, it is likely that many of these faults predate the Paintbrush Tuff and Calico Hills. The abundance of faults at depth may represent breakage from preCalico Hills strike-slip activity on the Sever Wash Fault zone, or other structures concealed beneath the Paintbrush Tuff.

Several additional drill holes would be necessary to determine the threedimensional geometry of the faults at depth, as well as the lateral eatent of the abundant pre-Calico Hills faults in the northeastern Yucca Mountain area. Such drill hole data could contribute to an understanding of the higher water table (Gemmeil, 1990) in this area by better defining the fault and fracture permeability at depth. 


\subsection{SENSE OF FAULT DISPLACEMENT}

The study also provided some information on the type of displacement on faults, as revealed by slickensides on the fault surfaces (Table 4-1). Of 117 faults with slickensides noted, only 29 percent were dip-slip, 52 percent were oblique slip, and 19 percent were horizontal slip. Oblique slip predominates at all locations except UE-25 a\#1, which probably has too few observations to be meaningful. USW G-2 stands out as having not only the most faults with slickensides observed, but also by far the most oblique displacements. No particular change in sense of slip with depth is obvious in the data (Appendix A), although faults appear to cluster in groups with similar slip vectors.

TABLE $4-1$

SENSE OF DISPLACEMENT FROM SLICRENSIDES ON FAULTS

IN DEEP DRILL HOLES AT YUCCA YOUNTAIN

(Rake angles: horlzontal-slip $0-30^{\circ}$;

oblique-silp $30^{\circ}-60^{\circ}$; dip-silp $60^{\circ}-90^{\circ}$ )

\begin{tabular}{|c|c|c|c|c|c|c|c|}
\hline \multirow[b]{2}{*}{ Drill hole } & \multirow[b]{2}{*}{ Dip-silp } & \multirow[b]{2}{*}{$(8)$} & \multicolumn{3}{|c|}{ Number of Observations } & \multirow[b]{2}{*}{$p(8)$} & \multirow[b]{2}{*}{ Total } \\
\hline & & & Oblique-slip & $(8)$ & Horizontal-slip & & \\
\hline UE-25 a\#1 & 3 & $(50)$ & 2 & (33) & 1 & (17) & 6 \\
\hline USW G-1 & 7 & (35) & 8 & $(40)$ & 5 & (25) & 20 \\
\hline USW G-2 & 14 & (23) & 37 & (62) & 9 & (15) & 60 \\
\hline USW GU-3/G-3 & 8 & (36) & $10^{1}$ & $(45)$ & 41 & (18) & 22 \\
\hline $\begin{array}{r}\text { USW G-4 } \\
\text { Total }\end{array}$ & $\frac{2}{34}$ & $\frac{(22)}{(29)}$ & $\frac{4}{61}$ & $\frac{(44)}{(52)}$ & $\frac{3}{22}$ & $\frac{(33)}{(19)}$ & $\frac{9}{117}$ \\
\hline
\end{tabular}

1 Two sets, oblique and horizontal slickensides, are present on one fault. 


\subsection{VERTICAL DISTRIBUTION OF FAULTS}

Except in drill hole UE-25 a\#1, there is an apparent increase in the number of faults below the Paintbrush Tuff or tuffs and lavas of Calico Hills (Figures 3-1 and 3-2). There are many intervals hundreds of feet thick, however, showing little or no evidence of faults (e.g., 1,200 to 1,800 feet and 3,370 to 3,750 feet in USW G-3; 300 to 700 feet in USW G-2; 500 to 800 feet, 1,400 to 2,200 feet, and 5,400 to 5,900 feet in USW G-1; 300 to 1,400 feet and 2,500 to 2,800 feet in USW $G-4 ; 1,400$ to 2,400 feet in UE-25 a\#1). Fractures are also rare to absent in many thick intervals.

Probably only two of the drill holes yield significant data with respect to the chronologic development of faults. USW G-1 and G-4 are located well away from significant surface faults and, in contrast to the other three holes, probably do not approach major fault zones at depth. In USW G-1, fault distribution appears to be fairly liniform throughout the hole, if the lava and flow breccia interval (Figure 3-1) is excluded. The brittle character of the lavas, together with their location within a thick section of less competent, poorly welded and nonwelded tuffs, may have concentrated stress in the lavas. The tuffs at those depths may have yielded more by plastic deformation than by faulting. USW G-4 penetrates to only about the middle of the Tram Member (Figure 3-2); but to that depth the fault distribution is fairly uniform. USW G-2 exhibits more faults at depth, below the tuffs of Calico Hil1s, but it is not clear whether this is a result of the proximity of the lower part of the hole to the Sever Wash Fault or to a set of older faults covered by the younger tuffs.

Thus, although it is difficult to draw a firm conclusion from the available drillhole data, 1 t appears that there is no consistent increase in the number of faults with depth. Although older faulting, unexposed at the surface, may occur in some areas. The end of significant faulting at the sfte area on Yucca Montain is constrained by the surface geology, which shows relatively large and generally equal displacement of the Tiva Canyon and underlying members of the Paintbrush Tuff, but only minor displacement of the Rainier Mesa Member of the Timber Mountain Tuff (Carr, 1984;"Scott and Bonk, 1984). 


\subsection{CALCITE OCCURRENCE}

Although calcite is proportionately a small constituent of the tuffs at Yucca Mountain, its occurrence, chiefly in voids and fractures in welded tuff in the unsaturated zone, is more common than many of the drill holes indicate. The importance of calcite at Yucca Mountain is twofold: (1) as a datable isotopic indicator of the timing and mechanism of water movement through the rock, and (2) as a factor in the possible generation of gaseous ${ }^{14} \mathrm{CO}_{2}$ from the repository to the surface.

During logging of structures in the core, obvious occurrences of calcite were noted and are summarized in Appendix 3 . This was done partly because the recording of calcite in existing drill-hole logs is inconsistent.

Identification of calcite was made entirely megascopically, as rules of the core storage facility prohibited destructive testing, including the use of hydrochloric acid. Many light-colored, fine-grained, very thin mineral coatings were observed that may be calcium carbonate in part, but most of these are not included in the summary in this report.

In general, calcite decreases in abundance with depth; it is most common in the welded portions of the Paintbrush Tuff in fractures, faults and lithophysae. In drill hole UE-25 a\#1, calcite is very rare below 1,200 feet (see also Spengler et al., 1979). One possible occurrence of fluorite was noted at $901 \mathrm{ft}$ in UE- 25 a\#1. Other fluorite occurrences are mentioned by Scott and Castellanos (1984, Table 11) in USW GU-3 and G-3. Opal, quartz, and chalcedony also occur locally with the calcite; these minerals were not recorded unless unusually abundant.

Although calcite is more abundant near the surface and there are many thick intervals lacking in calcite at depth, deeper zones of calcite occur, especially in holes USW G-1 and G-2 between approximately 3,500 and 6,000 feet. In USW GU-3 and G-3, little void-filling calcite occurs between approximately 650 and 1,700 feet, and between 3,300 and 4,300 feet. Very little secondary calcite occurs in hole USW G-4, even in the Paintbrush Tuff, and in that hole calcite is the least abundant of all types of fracture coatings (Spengler and Chornack, 1984; Carlos, 1987).

The interpretation favored in this report is that most of the calcite observed in the Paintbrush Tuff in the subsurface was derived from Quaternary surficial deposits of aeolian calcium carbonate-rich sand, remnants of which remain on the surface as sand ramps (Hoover, 1989). Leaching of the carbonate available for downward transport could have been enhanced during periods of higher Pleistocene precipitation, which supported more vegetation, stabilized the dunes, and created slightly acidic soil conditions favorable to solution of calcium carbonate at the surface. 


\subsection{CONCLUSIONS}

of the five drill holes examined, only USW G-1 perhaps is deep enough and sufficiently removed from complex fault zones to be a valid sample of the third dimensional aspects of extensional faults at Yucca Mountain. Taken as a whole, however, the available data on both the attitude of faults and dip of strata suggest that there is no tendency for faults to flatten substantially or for stratal dips to increase with depth. As there is no indication of significant ductile or small-scale deformation in the existing drill-hole core, it is likely that if a detachment exists at Yucca Mountain it probably lies at a depth well below present exploration.

Although the question of whether a significant episode of faulting preceded the Paintbrush Tuff or tuffs of Calico Hills at Yucca Mountain is generally unresolved, data from drill hole USW G-2 suggests the possibility of significant older faulting in some areas. Clearly, faults are more numerous in lavas and flow breccia beneath the Tran Member, but this may be a function, in part at least, of the mechanical properties of the lavas.

Calcite is most common in openings in the welded Paintbrush Tuff, although it also occurs sporadically below approximately 3,500 feet. Calcite is least common in USW G-4, hich could be the result of its location in an area of minimal faults and fractures.

Finally, in order to resolve the fundamental and tectonically important questions of fault geometry at Yucca Mountain, several three-point groups of holes should be drilled to recover oriented core in locations that will intersect and define faults or fault zones typical of the prominent structural grain. 


\section{REFERENCES}

Anderson, R. E, 1971, "Thin-Skin Distension in Tertiary Rocks of Southeastern Nevada," Geological Society of America Bulletin, v 82, p.
45-58. (HQS.880517.1041)

Angelier, J., and Colletta, B, 1983. "Tension Fractures and Extensional Tectonics," Nature, v. 301, p. 49-51. (NNA.920512.0106)

Carlos, B. A. 1987. "Minerals in Fractures of the Saturated Zone From Drill Core USW G-4, Yucca Mountain, Nye Caunty, Nevada," Los Alamos Report LA-10927-MS, 32 p. (NNA. 870708.0026)

Carr, W. J, 1984. "Regional Structural Setting of Yucca Mountain, Southwestern Nevada, and Late Cenozolc Rates of Tectonic Activity in Part of the Southwestern Great Basin, Nevada and California," U.S. Geological Survey Open-File Report 84 854, 109 p. (NNA.870325.0475)

Gemmel1, J. M., 1990. "Water Levels in Periodically Measured Wells in the Yucca Mountain Area Nevada, 1988," U.S. Geological Survey Open-File Report 90-113, 47 p. (NNA.900221.0001)

Hamblin, W. K., 1965. "Origin of 'Reverse Drag' on the Downthrown Side of Normal Faults:" Geological Society of America Bulletin, v. 76, p. 11451164. (NNA.920505.0073)

Hoover, D. L., 1989. "Preliminary Description of Quaternary and Late Pliocene Surficial Deposits at Yucca Mountain and Vicinity, Nye County, Nevada,". U.S. Geological Survey Open-File Report 8;-359, 45 p. (NNA.900403.0406)

Maldonado, F., and Koether, S. L., 1983. "Stratigraphy, Structure, and Some Petrographic Features of Tertiary Volcanic Rocks at the USW G-2 Drill Hole, Yucca Mountain, Nye County, Nevada," Y.S. Geological Survey OpenFile Report 83-732, 83 p. (HQS.880517.1329)

Miller, E. L., Gans, P. B., and Garling, J., 1983. "The Snake Range Decollement: An Exhumed Mid-Tertiary Ductile-Brittle Transition," Tectonics, v. 2, p. 239-263. (HQS.880517.3240)

Scott, R. B., 1990. "Tectonic Setting of Yucca Mountain, Southwest Nevada," Geological Society of America Memoir 176, Chapter 12, p. 251-282. (NNA. 910923.0009)

Scott, R. B., and Bonk, J., 1984. "Preliminary Geologic Map of Yucca Mountain, Nye County Nevada, With Geologic Sections, "U.S. Geological Survey Open-File Report 84-494, $9 \mathrm{p}$. and map, scale $1: 12,000$.
(HQS.880517.1443)

Scott, R. B., and Castellanos, M., 1984. "Stratigraphic and Structural Relations of Volcanic Rocks in Drill Holes USW GU-3 and USW G-3, Yucca Mountain, Nye County, Nevada," U.S. Geological Survey Open-File Report $84-$
491,121 p. (NNA.890804.0017) 
Spengler, R. W., Muller, D. C., and Livermore, R. B., 1979. "Preliminary Report on the Geology and Geophysics of Drill Hole UE-25 a\#1, Yucca Mountain, Nevada Test Site," U.S. Geological Survey Open-File Report 791244,43 p. (HQS.880517.1491)

Spengler, R. W., Byers, F. M., Jr., and Warner, J. B., 1981. "Stratigraphy and Structure of Volcanic Rocks in Drill Hole USW G-1, Yucca Mountain, Nye County, Nevada," U.S. Geological Survey Open-File Report 81-1349, 50 p. (HQS .880517.1492)

Spengler, R. W., and Chornack, M. P., 1984. "Stratigraphic and Structural Characteristics of Volcanic Rocks in Core Hole USW G-4, Yucca Mountain, Nye County, Nevada," U.S. Geological Survey Open-File Report 84-789, 77 p. (NNA.870519.0105)

Wernicke, B. P., and Burchfiel, B. C., 1982. "Modes of Extensional Tectonics," Journal of Structural Geology, v. 4, p. 105-115. (HQS.880517.1565)

Zoback, M. L., Anderson, R. E., and Thompson, G. A., 1981. "Cainozoic Evolution of the State of Stress and Style of Tectonism of the Basin and Range Province of the Western United States," Philosophical Transactions of the Royal Society of Loudon, Ser. A, v. 300, p. 407-434.

(HQS. 880517.1588) 
APPENDIX A

$-16$. 


\section{SURAYARY OF FAULTS AND SELECTED FRACTURES IN DEEP CORED DRILL HOLES AT YUCCA MOUNTAIN}

Depths measured to nearest 1.0 feet, dips to nearest $5^{\circ}$. I-Dip indeterminant.

Fractures noted are prominent natural breaks without breccia or obvious displacement. Fractures whose dips were not determined are not listed.

Faults characterized as "small" or "very small" have identical 1ithology on either side, the zone of slippage is relatively narrow ( $<3 / 8 \mathrm{in.}$ ), and the walls are not obviously brecciated or altered. "Small" faults have displacements of an inch or so; faults with "very small" displacement show evidence of slight movement (slickensides), but no measureable offset of textures or stratification.

The terms dip-slip, oblique, and horizontal displacement refer to the general attitude of slickensides observed on fault plane.

\section{UE - 25 a\#1 \\ (No core 0 to $54 \mathrm{ft}$ )}

\begin{tabular}{|c|c|c|c|c|}
\hline Structure & Depth ( $f t)$ & Dip & Displacement & Characteristics \\
\hline Faults & $188-190$ & I & & Clay, broken \\
\hline Faults & $193.5-195$ & I & & Clay, broken \\
\hline Fault & 225 & $55^{\circ}$ & Smal1 & \\
\hline Fault & 249 & $65^{\circ}$ & Small, dip-slip & \\
\hline Fault & 251.5 & $55^{\circ}$ & Small, oblique & \\
\hline Faults & $264-267$ & $\mathrm{I}$ & & Clay, broken \\
\hline Faults & $270-271$ & I & & Clay, broken \\
\hline Faults & $302-314$ & I & & Clay, broken \\
\hline Fault & 314.5 & $75^{\circ}$ & Small, dip-slip & \\
\hline Fracture & 361 & $60^{\circ}$ & & \\
\hline Faults & $429-440$ & I & & Clay, breccia \\
\hline Faults & $520-530$ & I & & Clay, breccia \\
\hline Fault & 645 & $85^{\circ}$ & & Clay \\
\hline Fracture & 648 & $70^{\circ}$ & & Planar \\
\hline Faults & $666.5-673$ & I & & Broken, breccia, clay \\
\hline Fractures & $675-676$ & $80^{\circ}$ & & \\
\hline Fracture & 683 & $80^{\circ}$ & & Planar \\
\hline Faults & $688-689$ & I & Small & \\
\hline Faults & $690-692$ & $85^{\circ}$ & Very small, oblique & Planar \\
\hline Fracture & 692 & $30^{\circ}$ & & Planar \\
\hline Fracture & 695 & $35^{\circ}$ & & Planar \\
\hline Faults & $709-714$ & I & & Broken \\
\hline Faults & $718-719$ & $75^{\circ}-80^{\circ}$ & & Breccia \\
\hline Fractures & $720-723$ & $75^{\circ}-85^{\circ}$ & & Planar \\
\hline Fracture & 729 & $40^{\circ}$ & & Planar \\
\hline Fracture & 731.5 & $50^{\circ}$ & & Planar \\
\hline Faults & $796-797.5$ & I & & $\begin{array}{l}\text { Stratigraphic } \\
\text { mismatch }\end{array}$ \\
\hline Fault & 806 & I & Small & 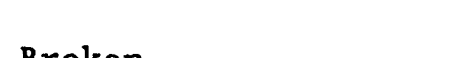 \\
\hline
\end{tabular}


UE- 25 a\#1

(Concluded)

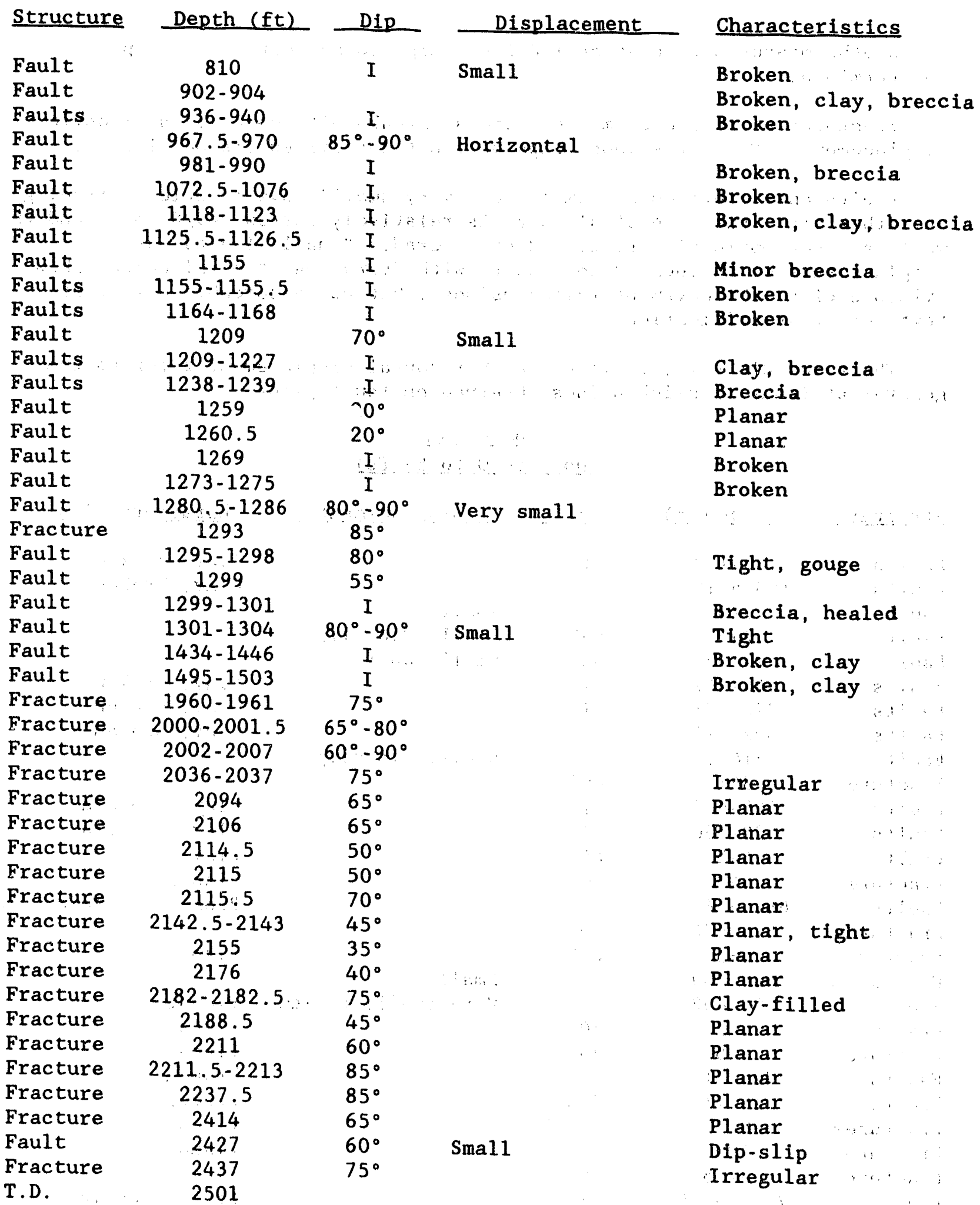


USW G-1

(No core 0 to $292 \mathrm{ft}$ )

\begin{tabular}{|c|c|c|c|c|}
\hline Structure & Depth (ft) & Dip & Displacement & Characteristics \\
\hline Fracture & 297 & $40^{\circ}$ & & Planar \\
\hline Fracture & 308 & $65^{\circ}$ & & Planar \\
\hline Fractures & $324-325$ & $85^{\circ}$ & & Open \\
\hline Fractures & $362-367$ & $85^{\circ}$ & & \\
\hline Fracture & 388 & $70^{\circ}$ & & Planar \\
\hline Fault & 428 & $20^{\circ}$ & & Crushing, clay \\
\hline Fracture & 524 & $60^{\circ}$ & & Planar \\
\hline Fracture & 568 & $85^{\circ}$ & $\cdots$ & Planar \\
\hline Fractures & $590-592$ & $80^{\circ}$ & & Planar \\
\hline Fracture & 716 & $75^{\circ}$ & & Planar \\
\hline Fractures & $723-724$ & $85^{\circ}$ & & Planax \\
\hline Fractures & $725.5-727$ & $80^{\circ}-90^{\circ}$ & & Planar \\
\hline Fractures & $727-727.5$ & $65^{\circ}$ & & Planar \\
\hline Fracture & 729.5 & $70^{\circ}$ & . & Planar \\
\hline Fracture & 730 & $20^{\circ}$ & & Planar \\
\hline Fracture & 736 & $70^{\circ}$ & & Planar \\
\hline Fractures & $743-744$ & $75^{\circ}-80^{\circ}$ & & Planar \\
\hline Fractures & $751-7.56$ & $70^{\circ}-90^{\circ}$ & & \\
\hline Fracture & 789.5 & $85^{\circ}$ & & \\
\hline Fractures & $803-80.5 .5$ & $75^{\circ}$ & & Planar \\
\hline Faults & $866-875$ & $70^{\circ}-90^{\circ}$ & Oblique & Broken \\
\hline Fracture & 947 & $80^{\circ}$ & & Planar \\
\hline Faults & $1117-1124$ & I & Simall & Clay, broken \\
\hline Faults & $1130-1142$ & I & & Breccia, broken \\
\hline Faults & $1157-1161$ & I & $\therefore$ & Broken \\
\hline Fracture & 1228 & $20^{\circ}$ & & Planar \\
\hline Fault & 1264.5 & $30^{\circ}$ & Small, dip-slip & \\
\hline Fault & 1266.5 & $30^{\circ}$ & Small, dip-slip & Broken \\
\hline Fracture & 1293 & $50^{\circ}$ & & Irregular \\
\hline Fractures & $1293.5-1298$ & $85^{\circ}$ & is $\therefore$ & Planar \\
\hline Fracture & 1299 & $40^{\circ}$ & & Planar \\
\hline Faults & $1305-1311$ & $85^{\circ}$ & $\begin{array}{l}\text { Very small, } \\
\text { horizontal }\end{array}$ & $\therefore$ \\
\hline Fault & 1318.5 & $\begin{array}{l}\text { low- } \\
\text { angle }\end{array}$ & $\because$ & Breccia \\
\hline Fault & 1329 & $50^{\circ}$ & Small & \\
\hline Faults & $1333-1335$ & $75^{\circ}$ & Dip-slip & \\
\hline Fractures & $1337-1339$ & $85^{\circ}$ & $i$ & Planar \\
\hline Fractures & $1352-1354$ & $85^{\circ}$ & & Planar \\
\hline Fractures & $1448-1449$ & $80^{\circ}$ & & Planar \\
\hline Faults & $1583-1585$ & I & Small & \\
\hline Fractures & 1827 & $10^{\circ}-45^{\circ}$ & & Tight \\
\hline Fault & 2282 & $75^{\circ}$ & Small, oblique & \\
\hline Faults & $2346.5-2347$ & $\mathrm{I}$ & Sma11 & Broken \\
\hline Fracture & 2450 & $80^{\circ}$ & & Tight \\
\hline Fracture & 2468 & $70^{\circ}$ & & Tight \\
\hline Fracture & 2498 & $75^{\circ}$ & & Tight \\
\hline Fractures & $2503-2506$ & $85^{\circ}$ & & Tight \\
\hline Fractures & $2530-2532$ & $80^{\circ}$ & & Tight \\
\hline
\end{tabular}


USW G-1

(Continued)

\begin{tabular}{|c|c|c|c|c|}
\hline Structure & Depth (ft) & Dip & Displacement & Characteristics \\
\hline $\begin{array}{l}\text { Fractures } \\
\text { Fractures }\end{array}$ & $\begin{array}{l}2538-2542 \\
2556-2558\end{array}$ & $\begin{array}{l}85^{\circ} \\
80^{\circ}\end{array}$ & & Tight \\
\hline Fault & 2578.5 & $30^{\circ}$ & Very sma11, dip-s1ip & $\begin{array}{l}\text { T1ght } \\
\text { Clay }\end{array}$ \\
\hline Fracture & 2673 & $10^{\circ}-20^{\circ}$ & & Tight \\
\hline Fault & 2778 & $40^{\circ}$ & & Gouge \\
\hline Fractures & $2786-2788$ & $50^{\circ}-85^{\circ}$ & & Minor openings \\
\hline Fractures & $2789-2791$ & $75^{\circ}$ & & Planar \\
\hline Fractures & $2796.5-2800$ & $85^{\circ}$ & & Planar \\
\hline Fracture & 2800 & $5^{\circ}-30^{\circ}$ & & Tight \\
\hline Fractures & $2849-2850.5$ & $75^{\circ}$ & & Tight, planar \\
\hline Fractures & $2905-2906$ & $70^{\circ}$ & & Planar \\
\hline Fractures & $2937-2938$ & $90^{\circ}$ & & Irregular \\
\hline Fracture & 2970 & $55^{\circ}$ & & Tight, planar \\
\hline Fracture & 3037 & $70^{\circ}-80^{\circ}$ & & Irregular \\
\hline Fractures & $3045-3048$ & $20^{\circ}-40^{\circ}$ & & Tight \\
\hline Fault & 3053 & $30^{\circ}$ & & \\
\hline Fault & 3057 & $25^{\circ}-40^{\circ}$ & & Tight \\
\hline Fault & 3063.5 & $30^{\circ}$ & $2 \mathrm{~cm}$ & Tight \\
\hline Fault & 3127 & I & & Clay, broken \\
\hline Fault & 3357.5 & $70^{\circ}$ & & Clay, broken \\
\hline Fault & 3394 & I & & Clay, broken \\
\hline Fault & 3522 & $25^{\circ}$ & & Gouge $2 \mathrm{~cm}$ wide \\
\hline Fault & 3553 & $65^{\circ}$ & & Tight \\
\hline Fracture & 3570 & $60^{\circ}$ & & \\
\hline Faults & $3586-3587$ & $70^{\circ}$ & & Tight \\
\hline Faults & $3588-3590$ & $70^{\circ}-80^{\circ}$ & & Tight \\
\hline Faults & $3601-3602$ & $75^{\circ}$ & Small & \\
\hline Faults & $3604-3607$ & I & Small, oblique & Irregular \\
\hline Fault & 3619 & $55^{\circ}$ & Small & Clay \\
\hline Fault & 3620 & $50^{\circ}$ & Small & Tight \\
\hline Faults & $3621-3622$ & I & & Cemented \\
\hline Faults & $3624-3625$ & I & & Gouge \\
\hline Fault & 3635 & $30^{\circ}$ & Sma11 & Clay \\
\hline Faults & $3638-3640$ & $75^{\circ}-90^{\circ}$ & Very small, oblique & Irregular \\
\hline Fault & 3648.5 & $75^{\circ}$ & Small & Clay \\
\hline Fault & 3650.5 & $35^{\circ}$ & Sma11, dip-slip & \\
\hline Fault & 3652 & $55^{\circ}$ & Sma11 & Clay \\
\hline Fault & 3653 & $65^{\circ}$ & Sma11 & Planar \\
\hline Fault & 3663 & $70^{\circ}$ & & Irregular \\
\hline Fracture & 3670 & $30^{\circ}$ & & Planar \\
\hline Fault & 3676 & $50^{\circ}$ & & Tight, clay \\
\hline Faults & 3730 & $60^{\circ}$ & & \\
\hline Fault & 3750 & $45^{\circ}$ & & \\
\hline Fault & 3764 & $40^{\circ}$ & Sma1l & \\
\hline Fault & 3773.5 & $30^{\circ}$ & & \\
\hline Fault & 3787 & $55^{\circ}$ & & \\
\hline Fault & 3794 & $35^{\circ}$ & & \\
\hline Faults & $3807-3807.5$ & $75^{\circ}$ & Horizontal & Irregular \\
\hline Fault & 3811 & $40^{\circ}$ & Sma11, oblique & \\
\hline
\end{tabular}


USW G-1

(Concluded)

\begin{tabular}{|c|c|c|c|c|}
\hline Structure & Depth $(f t)$ & Dip & Displacement & Characteristics \\
\hline & $\begin{array}{c}3847-3848.5 \\
3874\end{array}$ & $80^{\circ}-85^{\circ}$ & Horizontal & Irregular \\
\hline $\begin{array}{l}\text { Fractures } \\
\text { Fault }\end{array}$ & $\begin{array}{l}3874 \\
3877.5\end{array}$ & $30^{\circ}-70^{\circ}$ & & Tight \\
\hline Fault & 3884 & $\begin{array}{l}50^{\circ} \\
65^{\circ}\end{array}$ & $\begin{array}{l}\text { Small, dip-slip } \\
\text { Small }\end{array}$ & Tight \\
\hline Fracture & 3890 & $25^{\circ}$ & & Tight \\
\hline Faults & $3908-3910$ & $50^{\circ}$ & Smal1 & \\
\hline Fault & 4245 & $60^{\circ}$ & Sma11 & Healed \\
\hline Fault & 4340 & $45^{\circ}$ & & Irregular, healed \\
\hline Faults & $4431-4432$ & $75^{\circ}$ & Small, oblique & Clay \\
\hline Faults & $4680.5-4686$ & $85^{\circ}-90^{\circ}$ & Horizontal & Tight \\
\hline Fractures & $4867-4876$ & $85^{\circ}$ & & Minor openings \\
\hline Fault & 4883 & $60^{\circ}$ & Sinall & Tight \\
\hline Fault & 4927 & $35^{\circ}$ & Sma11 & Tight \\
\hline Fracture & 5002 & $50^{\prime \prime}$ & & \\
\hline Fault & 5057 & $6 c^{\circ}$ & Small, oblique & Clay \\
\hline Fault & 5059 & $65^{\circ}$ & Small & Clay \\
\hline Fault & 5067 & $60^{\circ}$ & Small, horizontal & \\
\hline Fault & 5084 & $50^{\circ}$ & Small, oblique & \\
\hline Fracture & 5086.5 & $50^{\circ}$ & & \\
\hline Fracture & 5312.5 & $75^{\circ}$ & & \\
\hline Fault & 5313 & $60^{\circ}$ & Small & Tight \\
\hline Faults & $5338-5340$ & $70^{\circ}$ & Dip-slip & $\begin{array}{l}\text { Irregular, clay, } \\
\text { broken }\end{array}$ \\
\hline Fracture & 5344 & $30^{\circ}$ & & \\
\hline Fault & 5348.5 & $80^{\circ}$ & & \\
\hline Fracture & 5349.5 & $50^{\circ}$ & & \\
\hline Fracture & 5368 & $85^{\circ}$ & & \\
\hline Fracture & 5429 & $75^{\circ}$ & & \\
\hline Fracture & 5466.5 & $70^{\circ}$ & & Tight \\
\hline Fracture & 5481 & $85^{\circ}$ & & Tight \\
\hline Fault & 5899 & $20^{\circ}$ & Small & \\
\hline T.D. & 6000 & & & \\
\hline
\end{tabular}

USW G-2

(No core 0 to $290 \mathrm{ft}$ )

\begin{tabular}{|c|c|c|c|c|}
\hline Structure & Depth (ft) & Dip 1 & Displacement & Characteristics \\
\hline Fracture & 300 & $10^{\circ}$ & & \\
\hline Fracture & 305 & $50^{\circ}$ & & Planar \\
\hline Fracture & 306 & $40^{\circ}$ & & Planar \\
\hline Fracture & 312 & $85^{\circ}$ & & Planar \\
\hline Fracture & 314.5 & $80^{\circ}$ & & Planar \\
\hline Fracture & 319 & $75^{\circ}$ & & Planar \\
\hline Fracture & 324 & $65^{\circ}$ & & Planar \\
\hline
\end{tabular}

$\overline{1 \text { Dips corrected }-5^{\circ}}$ below 4,200 ft to compensate for drill-hole deviation. 
USW G-2

(Continued)

\begin{tabular}{|c|c|c|c|c|}
\hline Structure & Depth (ft) & Dip 1 & Displacement & Characteristics \\
\hline Fracture & $336-337$ & $80^{\circ}$ & & Planar \\
\hline Fracture & 560 & $50^{\circ}-60^{\circ}$ & & \\
\hline Fracture & 581 & $70^{\circ}$ & & \\
\hline Fracture & 586 & $80^{\circ}$ & & \\
\hline Fracture & $619-620$ & $70^{\circ}-85^{\circ}$ & & \\
\hline Fracture & $645-647$ & $80^{\circ}$ & & Open \\
\hline Fracture & 653 & $70^{\circ}-80^{\circ}$ & & open \\
\hline Fracture & 658 & $70^{\circ}-80^{\circ}$ & & \\
\hline Fracture & 661 & $70^{\circ}-80^{\circ}$ & & \\
\hline Fracture & 670 & $90^{\circ}$ & & \\
\hline Fracture & 672 & $80^{\circ}$ & & \\
\hline Fracture & 770 & $50^{\circ}$ & & \\
\hline Fault & 789 & $20^{\circ}$ & Very small, oblique & \\
\hline Fault & 790 & $10^{\circ}$ & Very small, oblique & \\
\hline Fracture & $813-818$ & $60^{\circ}$ & & \\
\hline Faults & $856.5-858$ & $70^{\circ}$ & & Breccia \\
\hline Faults & $867-870$ & $\mathrm{I}$ & Smal1 & Broken \\
\hline Faults & $913-920.5$ & $85^{\circ}$ & $0.5 \mathrm{~cm}$ & Broken \\
\hline Fault & 920.5 & $30^{\circ}$ & Small & Tight \\
\hline Faults & $923.5-931$ & $75^{\circ}$ & & Breccia \\
\hline Faults & $939-942$ & $45^{\circ}$ & Small & Broken \\
\hline Faults & $977-983$ & $65^{\circ}-80^{\circ}$ & & Breccia \\
\hline Fault & 985.5 & $65^{\circ}$ & Small & \\
\hline Faults & $1157-1180$ & $80^{\circ}$ & -1 & Broken, breccia \\
\hline Faults & $1183-1185$ & $I$ & & Breccia \\
\hline Faults & $1249-1252$ & $70^{\circ}$ & Small & Broken \\
\hline Faults & $1264-1265$ & $70^{\circ}$ & Oblique & Broken, breccia \\
\hline Faults & $1277-1280$ & $65^{\circ}-75^{\circ}$ & Small & Minor breccia \\
\hline Faults & $1300-1310$ & $65^{\circ}-90^{\circ}$ & Horizontal & Breccia \\
\hline Faults & $1358-1366$ & $65^{\circ}-90^{\circ}$ & & Breccia \\
\hline Faults & $1376-1387$ & $70^{\circ}-80^{\circ}$ & & Breccia, openings \\
\hline Fault & 1409 & I & & Breccia \\
\hline Faults & $1419-1422$ & I & & Brecria \\
\hline Faults & $1441-1452$ & I & & Minor breccia \\
\hline Faults & $1461-1468$ & I & 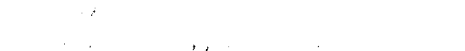 & Minor breccia \\
\hline Faults & $1470-1487$ & I & $\because \ldots$ & Minor breccia \\
\hline Fault & 1494 & I & & Breccia \\
\hline Faults & $1538-1539$ & $70^{\circ}$ & $\therefore$ & Breccia \\
\hline Faults & $1552-1555$ & $75^{\circ}-90^{\circ}$ & & Breccia \\
\hline Fault & 1576 & $70^{\circ}$ & & Breccia \\
\hline Faults & $1604-1608.5$ & I & & Breccia \\
\hline Fault & 1642 & $50^{\circ}$ & & \\
\hline Fault & 1643 & $45^{\circ}$ & & \\
\hline Fault & 1645 & $80^{\circ}$ & & \\
\hline Faults & $\begin{array}{l}1655-1657 \\
1669-1671\end{array}$ & $30^{\circ}-60^{\circ}$ & & Breccia \\
\hline Faults & $1669-1671$ & $30^{\circ}-60^{\circ}$ & & Breccia \\
\hline
\end{tabular}

$\overline{{ }^{1} \text { Dips corrected }-5^{\circ}}$ below 4,200 ft to compensate for drill-hole deviation. 
USW G-2

(Continued)

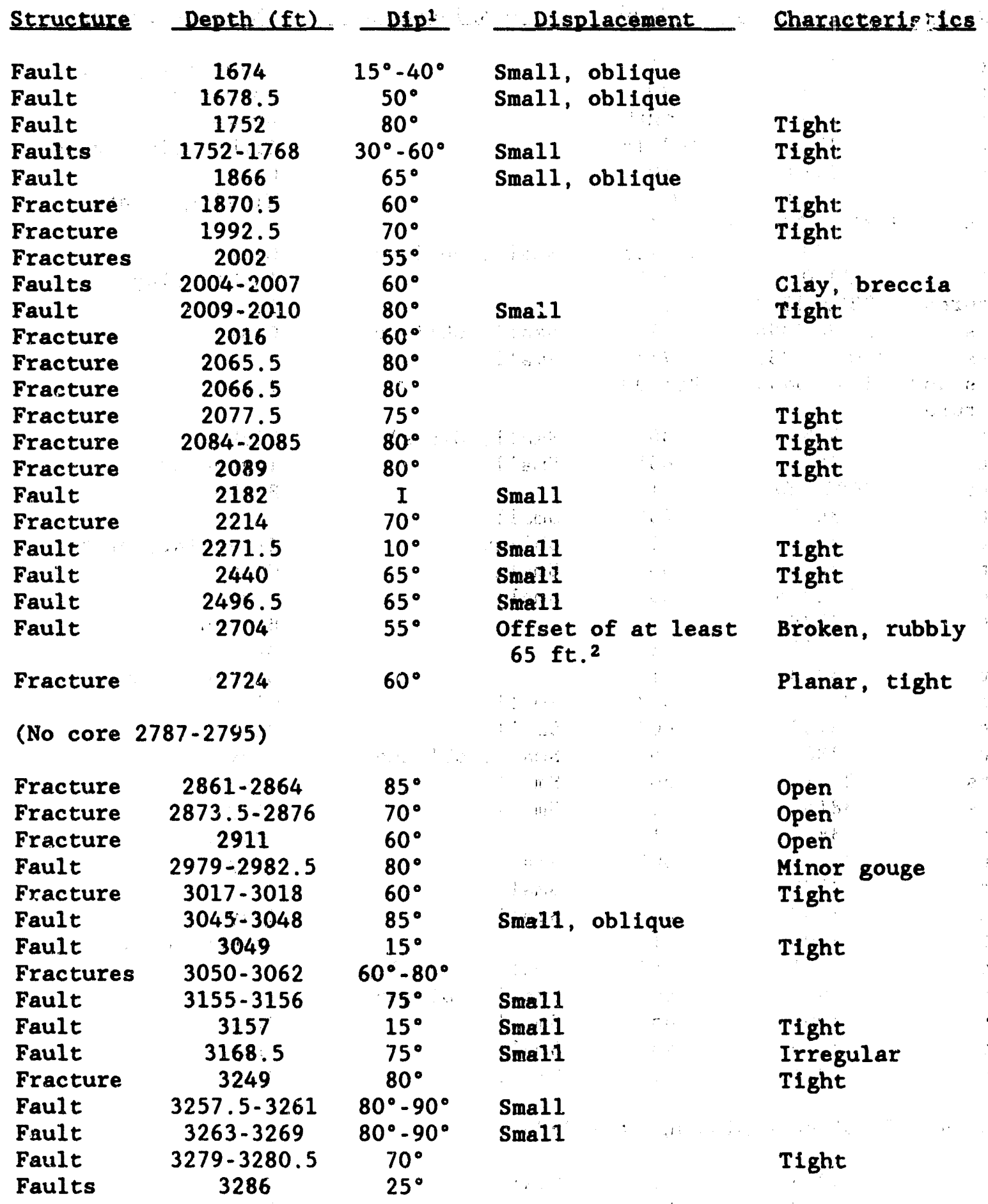

\footnotetext{
1Dips corrected $-5^{\circ}$ below 4,200 ft to compensate for drill-hole deviation.

${ }^{2}$ From Maldonado and Koether (1983).
} 
USW G-2

(Continued)

\begin{tabular}{|c|c|c|c|c|}
\hline structure & Depth (ft) & Dipl & Displacement & Characteristics \\
\hline Fault & 3288 & I & & Tight irregular \\
\hline Fault & 3289 & $70^{\circ}$ & & Openings \\
\hline Fault & 3290 & $<50^{\circ}$ & & Broken \\
\hline Fault & 3293 & $10^{\circ}-15^{\circ}$ & & Tight, minor gouge \\
\hline Fault & 3319 & $10^{\circ}$ & & Clay \\
\hline Fault & 3330 & $65^{\circ 2}$ & & Missing strata \\
\hline Faults & $3337.5-3338.5$ & $\mathbf{I}$ & & \\
\hline Fault & 3339 & $60^{\circ}-65^{\circ}$ & Smal1, oblique & Clay \\
\hline Fault & 3350.5 & $55^{\circ}$ & & Tight, clay \\
\hline Fractures & $3387-3392$ & $85^{\circ}$ & & Tight \\
\hline $\begin{array}{l}\text { Faults } \\
\text { Faults }\end{array}$ & $\begin{array}{c}3396-3398 \\
3407-3408.5\end{array}$ & $\begin{array}{c}I \\
75^{\circ}\end{array}$ & $\begin{array}{l}\text { Small, oblique } \\
\text { Small }\end{array}$ & Clay \\
\hline $\begin{array}{l}\text { Faults and } \\
\text { fractures }\end{array}$ & $3440-3444$ & $85^{\circ}-90^{\circ}$ & & Tight \\
\hline Fault & 3459 & $30^{\circ}$ & Small, dip-slip & Tight \\
\hline Fault & 3679 & $65^{\circ}$ & Small & Irregular \\
\hline Faults & $3684-3686$ & I & & Broken \\
\hline Fault & 3697 & $25^{\circ}$ & Small & \\
\hline Fault & 3700 & I & Oblique & Irregular, broken \\
\hline Fault & 3720 & $50^{\circ}$ & Smali & Clay \\
\hline Fault & 3720.5 & $35^{\circ}$ & Small & Clay \\
\hline Fault & 3728 & I & & Broken \\
\hline Fault & 3735 & I & & Broken \\
\hline Fault & 3753 & I & & Broken, clay \\
\hline Fault & 3755.5 & $50^{\circ}$ & Small & Clay \\
\hline Fault & 3762 & $60^{\circ}$ & Small & Clay \\
\hline Fault & 3804 & $55^{\circ}$ & Small, oblique & Clay \\
\hline Faults & 3811.5 & $50^{\circ}$ & Small & Clay \\
\hline Faults & 3815.5 & $\mathbf{I}$ & Small & Clay \\
\hline Fault & 3851 & I & & Broken \\
\hline Fault & 3865.5 & $50^{\circ}$ & Small & Clay \\
\hline Fault & 3885 & $70^{\circ}$ & Small & \\
\hline Fault & 3887 & $60^{\circ}$ & Small & Clay \\
\hline Fault & 3896 & I & & Broken, clay \\
\hline Fault & 3901 & $25^{\circ}$ & Small, dip-slip & \\
\hline Fault & 3902 & $60^{\circ}$ & Small, oblique & \\
\hline Fault & 3905 & $45^{\circ}$ & Small & Clay \\
\hline Fault & 3916 & $45^{\circ}$ & Small & Clay \\
\hline Fault & 3971 & I & Small & Clay \\
\hline
\end{tabular}

(About $9.5 \mathrm{ft}$ of core missing at $\pm 3980 \mathrm{ft}$ )

$\begin{array}{lllll}\text { Fault } & 3989 & \text { I } & \text { Small } & \text { Clay } \\ \text { Fault } & 4000 & 40^{\circ} & \text { Small } & \text { Tight } \\ \text { Fault } & 4001 & 30^{\circ} & \text { Small, dip-slip } & \text { Tight } \\ \text { Fault } & 4004 & 35^{\circ} & \text { Small } & \text { Tight } \\ \text { Fault } & 4007.5 & 55^{\circ} & \text { Small, dip-slip } & \text { Clay }\end{array}$

$\overline{{ }^{1} \text { Dips corrected }-5^{\circ}}$ below 4,200 ft to compensate for drill-hole deviation. 
USW G-2

(Continued)

\begin{tabular}{|c|c|c|c|c|}
\hline Structure & Depth (ft) & Dip ${ }^{1}$ & Displacement & Characteristics \\
\hline Fault & 4044 & $35^{\circ}$ & Small & Tight \\
\hline Fault & 4047 & $40^{\circ}$ & Small, horizontal & Tight \\
\hline Fault & 4051.5 & $55^{\circ}$ & Small & Tight \\
\hline Fault & 4061.5 & $40^{\circ}$ & Small & \\
\hline Fault & 4077 & $45^{\circ}$ & Dip-slip & Clay \\
\hline Fault & 4084 & $45^{\circ}$ & Small & \\
\hline Faults & $4086-4091.5$ & I & Small & \\
\hline Fault & 4103.5 & $40^{\circ}$ & Smal1 & \\
\hline Fault & 4105 & $40^{\circ}$ & Small, dip-slip & \\
\hline Faults & $4107-4115$ & $50^{\circ}$ & & \\
\hline Fracture & 4117 & $70^{\circ}$ & & Tight \\
\hline Fault & 4122 & $50^{\circ}-90^{\circ}$ & Small, oblique & \\
\hline Faults & $4146-4146.5$ & $50^{\circ}-60^{\circ}$ & Small, oblique & \\
\hline Faults & 4147 & $40^{\circ} ; 60^{\circ}$ & Small, dip-slip & \\
\hline Fault & 4148 & $55^{\circ}$ & Sma11, dip-slip & \\
\hline Fault & 4149 & $65^{\circ}$ & Small, oblique & \\
\hline Fault & 4152 & $50^{\circ}$ & Smal1, oblique & \\
\hline Fault & 4153 & $45^{\circ}$ & Small, dip-slip & \\
\hline Fault & 4154 & $50^{\circ}$ & Small, dip-slip & \\
\hline Fault & $4162.5-4163.5$ & $75^{\circ}$ & Small & Tight \\
\hline Fault & 4171 & $60^{\circ}$ & Small, dip-slip & \\
\hline Fault & 4183 & $60^{\circ}$ & Small, oblique & Clay \\
\hline Fault & 4196 & I & Small & Irregular \\
\hline Fault & 4199 & I & Small & Irregular \\
\hline Fault & 4199.5 & I & & Broken \\
\hline Fault & 4203 & $40^{\circ}$ & Small, oblique & \\
\hline Fracture & 4263.5 & $65^{\circ}$ & & Tight \\
\hline Fault & 4264.5 & $40^{\circ}$ & Smal1 & \\
\hline Fault & $4270-4272$ & $80^{\circ}$ & Small, horizontal & Tight \\
\hline Fault & 4283 & $55^{\circ}$ & Small & \\
\hline Fault & 4285 & $65^{\circ}$ & Small, oblique & \\
\hline Fault & 4316 & $60^{\circ}$ & Small & \\
\hline Faults & $4317-4320$ & I & Small & Irregular \\
\hline Fault & 4351 & I & Smal1 & \\
\hline Faults & $4354-4356$ & I & & Broken \\
\hline Fault & $4356-4359$ & $75^{\circ}$ & Small, horizontal & Clay \\
\hline Fault & 4522.5 & I & Small & \\
\hline Fault & 4523.5 & $55^{\circ}$ & Small, horizontal & Clay \\
\hline Faults & $4527-4529$ & $45^{\circ}-60^{\circ}$ & Sma11 & \\
\hline Fault & 4531 & $55^{\circ}$ & Small, oblique & \\
\hline Fault & 4534 & $65^{\circ}$ & Small, oblique & Clay \\
\hline Fault & 4551 & $55^{\circ}$ & Small, oblique & \\
\hline Fault & 4557 & I & & Irregular \\
\hline Fracture & 4602 & $55^{\circ-}$ & & Planar \\
\hline Fault & $4618-4619$ & $75^{\circ}$ & Small, dip-slip & \\
\hline
\end{tabular}

$\overline{1}$ Dips corrected $-5^{\circ}$ below $4,200 \mathrm{ft}$ to compensate for drill-hole deviation. 
USW G-2

(Continued)

\begin{tabular}{|c|c|c|c|c|}
\hline Structure & Depth $(f t)$ & Dip' & Displacement & Characteristics \\
\hline Fault & 4672 & $65^{\circ}$ & & Clay, gouge \\
\hline Fault & 4703 & $20^{\circ}$ & Sma11, oblique & \\
\hline Faults & $4709.5-4720$ & I & (No core, probable & fault zone) \\
\hline Fault & 4729 & $40^{\circ}$ & Small & \\
\hline Fault & 4745 & $45^{\circ}$ & & Shears \\
\hline Fault & 4770 & I & Smal1 & Irregular \\
\hline Fracture & 4806 & $55^{\circ}$ & & Tight, planar \\
\hline Fault & 4811 & $45^{\circ}$ & Smal1 & Tight \\
\hline Fault & 4813 & $60^{\circ}$ & Smal1 & Tight \\
\hline Faults & $4816-4818$ & $45^{\circ}$ & & Breceia \\
\hline Fault & 4820 & $45^{\circ}$ & Smal1 & \\
\hline Fault & 4831.5 & $55^{\circ}$ & Small & Irregular \\
\hline Fault & 4833 & $45^{\circ}$ & Smal1 & Irregular \\
\hline Faults & $4848-4850$ & I & Small & Broken \\
\hline Fault & 4851.5 & $55^{\circ}$ & Smal1 & $\therefore \quad:$ \\
\hline Fault & 4868 & $50^{\circ}$ & Small & \\
\hline Fault & $4869-4870$ & $70^{\circ}$ & Sma11, oblique & \\
\hline Faults & $4873-4874$ & I & & \\
\hline Faults & $4876-4877$ & I & & \\
\hline Fault & 487.9 & $45^{\circ}$ & Sma11, oblique & $\therefore:$ \\
\hline Faults & $4882-4893$ & I & & Broken \\
\hline Fault & 4895 & I & & Irregular \\
\hline Fault & 4896.5 & $55^{\circ}$ & Qblique & Breccia, clay \\
\hline Fault & 4907.5 & $45^{\circ}$ & Small, dip-slip & Tight \\
\hline Fault & 4909 & $\mathbf{I}$ & & Broken \\
\hline Faults & $4910-4921$ & I. & : : & Irregular \\
\hline Faults & $4926-4927$ & I & & Broken \\
\hline Faults & $4929-4932$ & I & & Broken \\
\hline Faults & $4938-4944$ & I & & Broken \\
\hline Faults & $4947-4950$ & I & & Broken \\
\hline Fault & 4955 & $40^{\circ}$ & & Tight \\
\hline Fault & 5019 & I & & Clay, low angle \\
\hline Faults & $5029-5030$ & I & & Breccia, clay, broken \\
\hline Faults & $5064-5068$ & I & & Broken \\
\hline Faults & $5082-5084$ & I & & Broken \\
\hline Faults & $5094-5096$ & I & & Broken \\
\hline Faults & $5100-5102$ & I & & Broken \\
\hline Fracture & 5116 & $70^{\circ}$ & & Tight \\
\hline Fault & 5170 & I & Small & Irregular \\
\hline Faults & $5174-5206$ & I & Major & Breccia, broken \\
\hline Fault & $5208-5809$ & $60^{\circ}-85^{\circ}$ & Small, horizontal & Irregular \\
\hline Faults & $5223-5224$ & $65^{\circ}$ & & Breccia \\
\hline Fault & $5263-5264.5$ & $80^{\circ}$ & Small, horizontal & Tight \\
\hline Fault & 5269 & $55^{\circ}$ & Small, oblique & Tight \\
\hline Fault & 5295 & $55^{\circ}-75^{\circ}$ & Small & Tight \\
\hline Fault & 5319 & $65^{\circ}$ & Small & Tight \\
\hline
\end{tabular}

$\overline{\text { Dips corrected }-5^{\circ}}$ below 4,200 ft to compensate for drill-hole deviation. 
USW G-2

(Concluded)

\begin{tabular}{|c|c|c|c|c|}
\hline Structure & Depth (ft) & Dip 1 & Displacement & Characteristics \\
\hline Fault & 5367.5 & $65^{\circ}$ & Small, horizontal & Tight \\
\hline Fault & 5372.5 & $60^{\circ}$ & Small, oblique & Tight \\
\hline Fractures & 5418 & $65^{\circ}$ & & \\
\hline Fault & 5514.5 & $65^{\circ}$ & Small & Tight \\
\hline Fault & 5563.5 & $35^{\circ}$ & Small & Tight \\
\hline Faults & 5597 & $20^{\circ} ; 40^{\circ}$ & Sma11 & Tight \\
\hline Fault & 5624 & $55^{\circ}$ & Small & Tight \\
\hline Fault & 5637 & $40^{\circ}$ & & \\
\hline Fault & 5672 & $50^{\circ}$ & Sma1l & Tight \\
\hline Fault & 5698 & $65^{\circ}$ & Small, oblique & Tight \\
\hline Fractures & 5757 & $65^{\circ}$ & & \\
\hline Fractures & $5765-5780$ & $30^{\circ}-75^{\circ}$ & & Tight \\
\hline Fault & 5780 & $65^{\circ}$ & Smal1, oblique & Tight \\
\hline Fault & 5809 & $45^{\circ}$ & $\therefore$ & \\
\hline Fault & 5833 & $70^{\circ}$ & & \\
\hline Fault & 5841 & $70^{\circ}$ & Oblique & $\therefore$ \\
\hline Fault & 5845 & $55^{\circ}$ & Horizontal & \\
\hline Fault & 5846.5 & $25^{\circ}$ & Oblique & \\
\hline Fault & 5849.5 & $55^{\circ}$ & Oblique & \\
\hline Fau1t & 5853.5 & $20^{\circ}$ & oblique & \\
\hline Fault & 5854 & $10^{\circ}$ & Dip-slip & \\
\hline Fault & 5855 & $60^{\circ}$ & oblique & \\
\hline Fault & 5870 & $70^{\circ}$ & & \\
\hline Fault & 5898 & $70^{\circ}$ & & \\
\hline Fault & 5906.5 & $60^{\circ}$ & oblique & \\
\hline Faults & $5912.5-5914$ & I & . & Broken \\
\hline Faults & $5919-5920.5$ & I & & Broken \\
\hline Fault & 5923.5 & $80^{\circ}$ & Small & \\
\hline Fault & 5930.5 & I & Small & Broken \\
\hline Fault & 5936 & $65^{\circ}$ & & \\
\hline Fault & 5985.5 & $50^{\circ}$ & oblique & \\
\hline T.D. & 6006 & & & \\
\hline
\end{tabular}

${ }^{1}$ Dips corrected $-5^{\circ}$ below 4,200 ft to compensate for drill-hole deviation. 2From Maldonado and Koether (1983).

\begin{tabular}{|c|c|c|c|c|}
\hline & & $\begin{array}{c}\text { US } \\
\text { (No } \\
\end{array}$ & $\begin{array}{l}-3 \text { and } G-3 \\
0 \text { to } 31 \mathrm{ft})\end{array}$ & \\
\hline structure & Depth $(f t)$ & Dip 1 & Displacement & Characteristics \\
\hline $\begin{array}{l}\text { Fault } \\
\text { Fracture }\end{array}$ & $\begin{array}{l}139 \\
149\end{array}$ & $\begin{array}{l}55^{\circ} \\
75^{\circ}\end{array}$ & Sma11 & $\begin{array}{l}\text { Breccia } \\
\text { Filled }\end{array}$ \\
\hline
\end{tabular}

Dips are corrected as follows for westerly drill-hole deviation (Scott and Castellanos, 1984), assuming all structures also dip westward: 0 to $820 \mathrm{ft}$ : $0^{\circ} ; 820$ to $2460 \mathrm{ft}:-5^{\circ} ; 2460$ to $3280 \mathrm{ft}:-10^{\circ} ; 3280$ to $4100 \mathrm{ft}:-15^{\circ} ; 4100$ to $5031 \mathrm{ft}:-20^{\circ}$. 
USW GU-3 and G-3

(Continued)

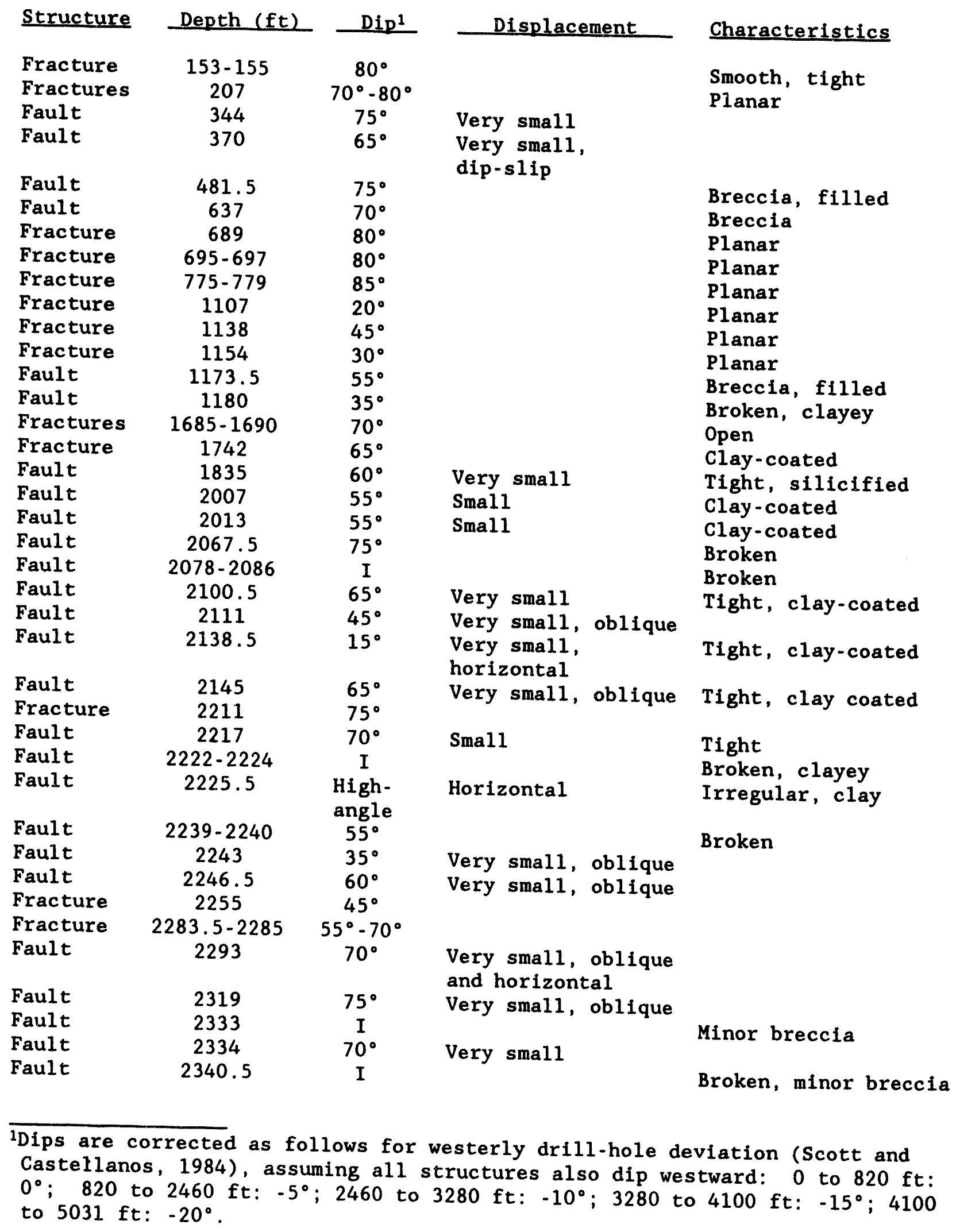


USW GU-3 and G-3

(Continued)

\begin{tabular}{|c|c|c|c|c|}
\hline Structure & Depth $(f t)$ & Dip 1 & Displacement & Characteristics \\
\hline Fault & $2341.5-2343$ & $60^{\circ}-75^{\circ}$ & Small & Tight \\
\hline Fault & $2382.5-2388$ & $\begin{array}{l}\text { High- } \\
\text { angle }\end{array}$ & $\begin{array}{l}\text { Very small, } \\
\text { horizontal }\end{array}$ & \\
\hline Fracture & 2470 & $20^{\circ}$ & & Planar \\
\hline Fault & 2542 & $45^{\circ}-55^{\circ}$ & Very small & \\
\hline Fault & 2555 & $65^{\circ}$ & Small & Tight \\
\hline Fault & 2559 & $65^{\circ}$ & $0.5 \mathrm{~cm}$ & \\
\hline Fault & 2587 & $65^{\circ}$ & & Broken \\
\hline Fault & 2595 & $60^{\circ}$ & Very small & \\
\hline Fault & 2606 & $65^{\circ}$ & Very small, dip-slip & \\
\hline Fault & 2606.5 & $50^{\circ}$ & Very small, dip-slip & \\
\hline Fracture & 2635 & $70^{\circ}$ & & Clay-coated \\
\hline Fault & 2653 & $50^{\circ}$ & Sma11 & \\
\hline Fracture & 2727 & $40^{\circ}$ & & Tight \\
\hline Fault & $2764-2768$ & $75^{\circ}$ & $0.5 \mathrm{~cm}$ & Minor openings \\
\hline Fault & 2816 & $55^{\circ}$ & Small, dip-slip & \\
\hline Fault & 2826 & $65^{\circ}$ & & Tight, minor breccia \\
\hline Fault & 2830 & $20^{\circ}$ & & Minor crushing \\
\hline Fracture & 2843 & $70^{\circ}$ & & Irregular \\
\hline Fault & 2847 & $70^{\circ}$ & $0.5 \mathrm{~cm}$ & \\
\hline Fault & $2876-2885$ & I & & $\begin{array}{l}\text { Fault zone, broken, } \\
\text { clayey }\end{array}$ \\
\hline Fractures & $2897-2912$ & $75^{\circ}$ & & Clay-coated \\
\hline Fault & 2931.5 & $65^{\circ}$ & & \\
\hline Fault & 2947 & $40^{\circ}$ & Small & \\
\hline Fracture & 2981.5 & $60^{\circ}$ & & \\
\hline Fracture & $3002.5-3005$ & $75^{\circ}$ & Ob1ique, pull-apart & \\
\hline Fault & $3009-3012$ & $75^{\circ}$ & Sma11 & \\
\hline Fracture & $3077-3080$ & $75^{\circ}$ & & Calcite-filled \\
\hline Fracture & $3082-3084$ & $75^{\circ}$ & & Calcite-filled \\
\hline Fracture & 3107 & $60^{\circ}$ & & Tight, planar \\
\hline Fault & $3290-3292$ & $65^{\circ}$ & $3 / 8$ in. & Tight \\
\hline Fault & $3363-3365$ & $60^{\circ}$ & Sma11 & Broken \\
\hline Fault & $3366-3368$ & $65^{\circ}$ & Small & Broken \\
\hline Fault & 3770 & $55^{\circ}$ & Smal1 & \\
\hline Fault & 3891 & $50^{\circ}$ & Small & Broken \\
\hline Fault & 4013 & $I$ & & Clayey \\
\hline Fault & 4040 & $55^{\circ}$ & Small, dip-slip & $\begin{array}{l}\text { Tight } \\
\text { Broken clavey }\end{array}$ \\
\hline Fault & $4052-4053$ & I & & $\begin{array}{l}\text { Broken, clayey } \\
\text { Broken clayey }\end{array}$ \\
\hline Fault & $\begin{array}{c}4115 \\
4297.5\end{array}$ & $55^{\circ}$ & Small & $\begin{array}{l}\text { Broken, clayey } \\
\text { Broken, clayey zone }\end{array}$ \\
\hline raute & 4297.5 & 40 & & as much as $5 \mathrm{~cm}$ wide \\
\hline Fault & 4334 & I & Small & Broken \\
\hline
\end{tabular}

\footnotetext{
1Dips are corrected as follows for westerly drill-hole deviation (Scott and Castellanos, 1984), assuming all structures also dip westward: 0 to $820 \mathrm{ft}$ : $0^{\circ} ; 820$ to $2460 \mathrm{ft}:-5^{\circ} ; 2460$ to $3280 \mathrm{ft}:-10^{\circ} ; 3280$ to $4100 \mathrm{ft}:-15^{\circ} ; 4100$ to $5031 \mathrm{ft}:-20^{\circ}$.
} 


\begin{tabular}{|c|c|c|c|c|}
\hline Structure & Depth $(f t)$ & Dip 1 & Displacement & Characteristics \\
\hline Fault & 4339 & $50^{\circ}$ & Small & \\
\hline Fault & 4353 & $55^{\circ}$ & Small & Clay coating \\
\hline Fault & 4354 & I & Smal1 & Clay coating \\
\hline Fault & 4379 & $\mathrm{I}$ & & Broken, clayey \\
\hline Fracture & 4399 & $50^{\circ}$ & & \\
\hline Fault & 4455 & $45^{\circ}$ & Small & Tight \\
\hline Fault & $4470-4472$ & $35^{\circ}-40^{\circ}$ & Dip-silp & Clay, breccia \\
\hline Fault & 4476 & $50^{\circ}$ & Small & Broken \\
\hline Fault & 4480 & $10^{\circ}$ & Small & Tight \\
\hline $\begin{array}{l}\text { Fracture } \\
\text { Faults }\end{array}$ & $\begin{array}{c}4487 \\
4500-4504\end{array}$ & $\begin{array}{c}20^{\circ} \\
65^{\circ}-70^{\circ}\end{array}$ & & Tight \\
\hline $\begin{array}{l}\text { Faults } \\
\text { Faults }\end{array}$ & $\begin{array}{l}4500-4504 \\
4514-4515\end{array}$ & $\begin{array}{c}65^{\circ}-70^{\circ} \\
55^{\circ}\end{array}$ & & Tight, filled \\
\hline Fault & 4540 & $55^{\circ}$ & $3 / 16$ in. & $\begin{array}{l}\text { Tight, filled } \\
\text { Tight }\end{array}$ \\
\hline Fault & 4559 & $35^{\circ}$ & Sma11, oblique & Clay-coated \\
\hline Fault & 4591 & $45^{\circ}$ & Small, oblique & \\
\hline Faults & $4599.5-4600.5$ & $45^{\circ}$ & Dip-silp & $\begin{array}{l}15 \mathrm{~cm} \text { wide, broker } \\
\text { silicified }\end{array}$ \\
\hline Fracture & 4619.5 & $10^{\circ}$ & & $\begin{array}{l}0.5 \mathrm{~cm} \text { wide, tight, } \\
\text { silicified }\end{array}$ \\
\hline $\begin{array}{l}\text { Fracture } \\
\text { Fault }\end{array}$ & $\begin{array}{c}4649-4650 \\
4652\end{array}$ & $\begin{array}{c}40^{\circ}-45^{\circ} \\
45^{\circ}\end{array}$ & " & Tight \\
\hline Fractures & $\begin{array}{l}4652 \\
4658\end{array}$ & $\begin{array}{l}45^{\circ} \\
20^{\circ}\end{array}$ & Small & $\begin{array}{l}\text { Tight } \\
\text { Tight }\end{array}$ \\
\hline Fault & 4671.5 & $30^{\circ}$ & Dip-slip & Tight \\
\hline Fault & 4778 & $25^{\circ}$ & Small, oblique & clay and chlorite \\
\hline Fault & 4803 & $30^{\circ}$ & Small & \\
\hline Fractures & $\begin{array}{l}4813 \\
4818\end{array}$ & $40^{\circ}$ & & Tight \\
\hline $\begin{array}{l}\text { Fault } \\
\text { Fault }\end{array}$ & $\begin{array}{c}4818 \\
4845.5\end{array}$ & $\because \quad \begin{array}{l}40^{\circ} \\
10^{\circ}\end{array}$ & Small & Calcite-filled \\
\hline $\begin{array}{l}\text { Fault } \\
\text { Fault }\end{array}$ & $\begin{array}{c}4845.5 \\
4943\end{array}$ & $\begin{array}{l}10^{\circ} \\
20^{\circ}\end{array}$ & Sma11, oblique & \\
\hline $\begin{array}{l}\text { Fault } \\
\text { T. D. }\end{array}$ & $\begin{array}{l}4943 \\
5031\end{array}$ & & Small & Clay-coated \\
\hline
\end{tabular}

\footnotetext{
${ }^{1 D i p s}$ are corrected as follows for westerly drill-hole deviation (Scott and Castellanos, 1984), assuming all structures also dip westward: 0 to $820 \mathrm{ft}$ : $0^{\circ} ; 820$ to $2460 \mathrm{ft}:-5^{\circ} ; 2460$ to $3280 \mathrm{ft}:-10^{\circ} ; 3280$ to $4100 \mathrm{ft}$ : $-15^{\circ} ; 4100$
to $5031 \mathrm{ft}:-20^{\circ}$.
}

\begin{tabular}{|c|c|c|c|c|}
\hline & & (No & $\begin{array}{l}\mathrm{G}-4 \\
\text { to } 41 \mathrm{ft})\end{array}$ & \\
\hline Structure & Depth $(f t)$ & Dip & Displacement & Characteristics \\
\hline $\begin{array}{l}\text { Fractures } \\
\text { Fault } \\
\text { Fault } \\
\text { Fault }\end{array}$ & $\begin{array}{c}64.5-65.5 \\
125 \\
197 \\
202\end{array}$ & $\begin{array}{l}80^{\circ} \\
30^{\circ} \\
55^{\circ} \\
75^{\circ}\end{array}$ & & $\begin{array}{l}\text { Slickensides } \\
\text { Broken }\end{array}$ \\
\hline
\end{tabular}


USW G-4

Continued

\begin{tabular}{|c|c|c|c|c|}
\hline Structure & Depth (ft) & Dip & Displacement & Characteristics \\
\hline Fault & 275.5 & $45^{\circ}$ & Very small & \\
\hline Fractures & $1182-1182.5$ & $70^{\circ}$ & & Planar \\
\hline Fracture & 1205.5 & $80^{\circ}$ & & Planar \\
\hline Fault & 1315 & I & & Clay \\
\hline Faults & $1318-1320$ & $85^{\circ}$ & More than $2.0 \mathrm{ft}$ & Clay \\
\hline Fractures & $1341-1346$ & $85^{\circ}-90^{\circ}$ & & Planar \\
\hline Fractures & $1346.5-1353.5$ & $85^{\circ}-90^{\circ}$ & & Planar \\
\hline Fault & $1406-1407$ & $70^{\circ}$ & & Breccia \\
\hline Faults & $1557-1557.5$ & $75^{\circ}$ & & Planar \\
\hline Faults & $1670.5-1671$ & $70^{\circ}$ & Smal1, oblique & \\
\hline $\begin{array}{l}\text { Faults } \\
\text { Faults }\end{array}$ & $\begin{array}{l}1895-1896 \\
1921-1925\end{array}$ & $\begin{array}{c}70^{\circ}-90^{\circ} \\
I\end{array}$ & Small, horizontal & Irregular \\
\hline Fault & 1947 & $40^{\circ}$ & Very small, oblique & \\
\hline Fault & 1956.5 & $50^{\circ}$ & Small, horizontal & \\
\hline Fault & 1991.5 & $70^{\circ}-80^{\circ}$ & Oblique & Breccia, gouge \\
\hline Fracture & 2066 & $40^{\circ}$ & & \\
\hline Faults & $2244-2247$ & $75^{\circ}$ & & \\
\hline Fractures & $2342-2346$ & $85^{\circ}$ & & \\
\hline Faults & $2438-2442.5$ & $85^{\circ}-90^{\circ}$ & Very small, oblique & \\
\hline $\begin{array}{l}\text { Fractures } \\
\text { Fracture }\end{array}$ & $\begin{array}{c}2438.5-2446.5 \\
2563-2571.5\end{array}$ & $\begin{array}{l}85^{\circ} \\
85^{\circ}\end{array}$ & & \\
\hline Fault & 2813 & $70^{\circ}$ & Small, dip-slip & \\
\hline Fault & 2886 & $40^{\circ}$ & Small, dip-slip & \\
\hline Faults & $2919-2923$ & $80^{\circ}-90^{\circ}$ & Very small, horizon & \\
\hline
\end{tabular}


APPENDIX B

$-32-$ 


\section{SECONDARY CALCITE OCCURRENCES IN CORE FROY FIVE DRILL HOLES AT YUCCA MOUNTAIN \\ (see text for discussion of observations)}

Defth (ft)

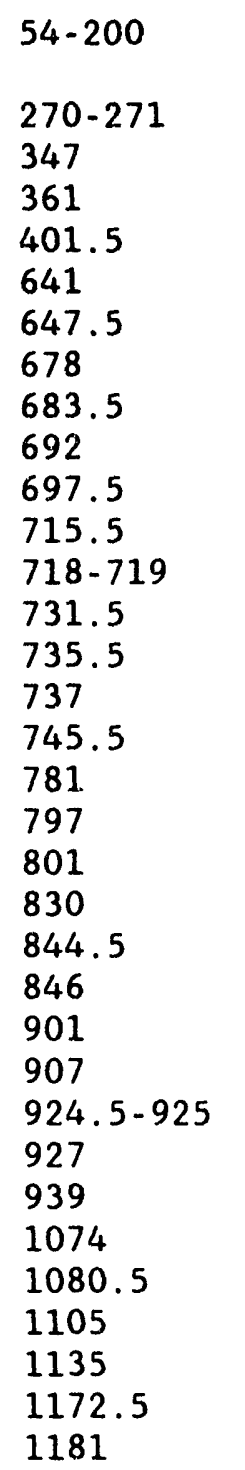

UE- 25 a\#1

(No core 0 to $54 \mathrm{ft}$ )

Some high-angle and many low-angle fractures with calcite coatings

Calcite and opal fracture coatings

Calcite on fractures

Calcite on fractures

Calcite on fractures

Calcite in cavities

Calcite in cavities

Calcite on fracture

Calcite on low-angle fracture

Calcice on low-angle fracture

Calcite on fracture

Calcite on fracture

$2 \mathrm{~cm}$ wide breccia with calcite

Planar fracture with calcite

Calcite in cavity

Calcite on fracture

Calcite on fracture

Calcite in cavity

Calcite in cavity

Calcite in cavity

Calcite in cavity

Calcite in cavity

Calcite in cavity

Calcite and/or fluorite in cavities

Calcite in cavity

Calcite in cavities

Calcite in cavity

Calcite in cavity

Calcite in cavities

Calcite in cavity

Calcite in cavity

Calcite on fracture

Calcite on fracture

Calcite on fracture

Only minor calcite below this point. 
Depth (ft)

$315-322$

425.5

439

491.5

568

579

619

668.5

681.5

695.5

725.5

960.5

1017

1025.5

1029

1113

1161

1199

1228.5

1265.5

1280-1285
USW G-1

(No core $0-292 \mathrm{ft}$ )

Calcite coatings on fractures

Calcite in cavity

Calcite in lithophysae

Calcite on irregular fracture

Very thin $(<1 \mathrm{~mm})$ carbonate coating on fiacture

Calcite crystals in cavity

Calcite in cavity

Calcite in lithophysae

Calcite in lithophysae

Calcite in lithophysae

Calcite coating on planar fracture

Calcite in cavity

Calcite in cavity

Calcite in cavity

Calcite in cavity

Calcite in cavity

Calcite in low-angle fracture

Calcite in cavity

Calcite in cavity

Calcite in fracture

Calcite on low-angle fractures

Thick interval with little or no calcite.

$3586-3587$
$3588-3590$
3596.5
$3638-3640$
3641.5
3642
3648.5
3676
$3822-3825$
$3868-3870$
3896
$4680.5-4686$
5086.5
5368

$3586-3587$

3596.5

$3638-3640$

3641.5

3642

3648.5

3676

$3822-3825$

$3868-3870$

$4680.5-4686$

5368

USW G-2

(No core 0 to $290 \mathrm{ft}$ )
Calcite in irregular fractures

Calcite sealing fault zone

Calcite filling irregular fracture

Calcite coating on irregular fault

Calcite in irregular fracture

Calcite in irregular fracture

Calcite in small fault

Calcite in tight fault

Calcite in irregular fracture

Calcite between clasts in tightly healed breccia

Calcite between clasts in breccia

Calcite filling tight fault

Calcite coating on fracture

Calcite-filled fracture
Depth (ft)

300

314.5

586

$619-620$

630-639
Occurrence

Minor calcite in fracture

Thin calcite coating on planar fracture

Calcite coating on irregular fractures

Calcite coating on irregular fractures

Calcite coating on irregular fractures 
USW G-2

Continued
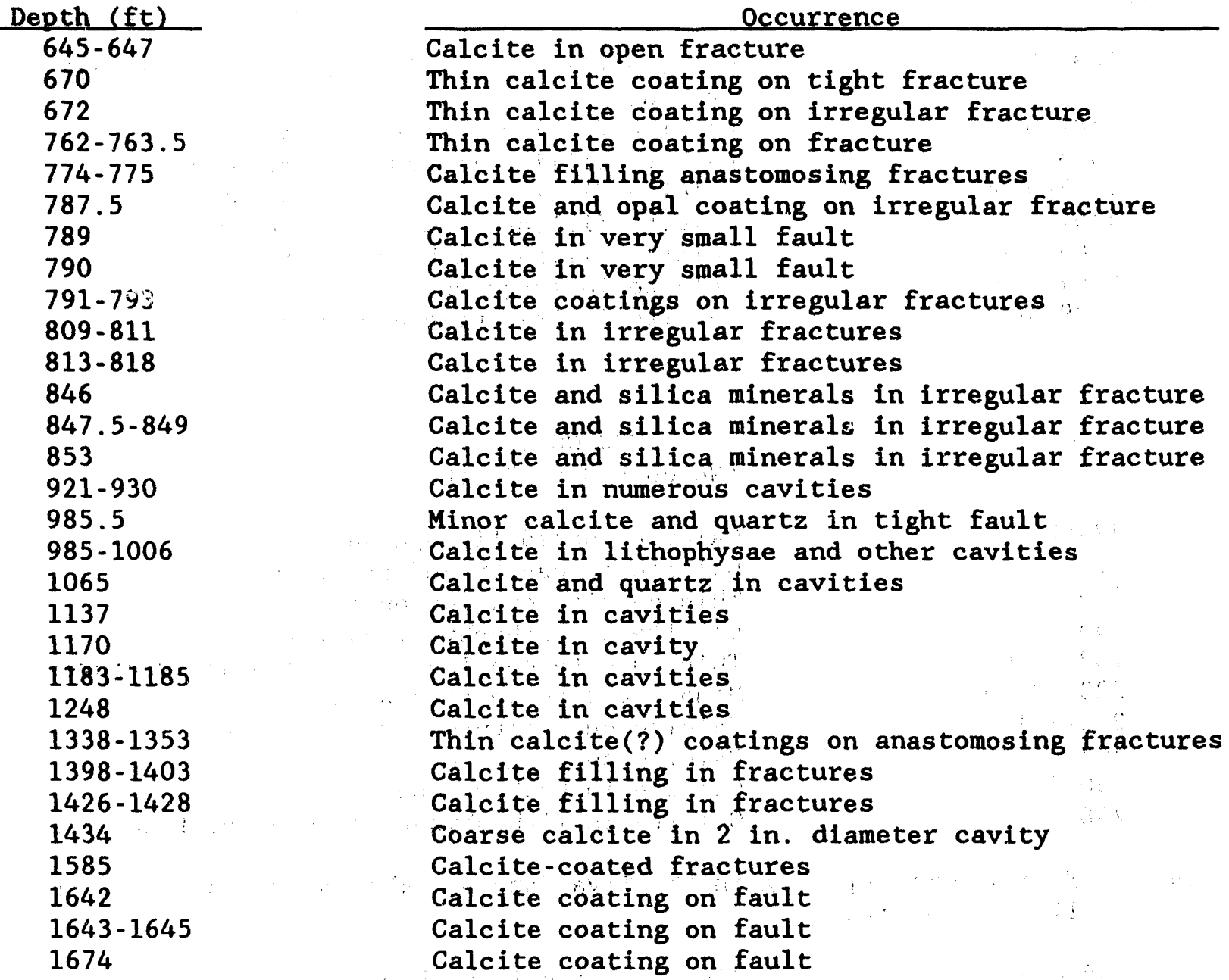

Thick interval with little or no calcite

$\begin{array}{ll}4107-4115 & \text { Calcite-coated fractures and small faults } \\ 4117 & \text { Calcite in tight fracture } \\ 4122 & \text { Calcite-coated small fault } \\ 4143.5 & \text { Minor calcite in irregular fracture } \\ 4908 & \text { Calcite-filled fracture } \\ 4910-4918 & \text { Calcite veins in fractures and small faults } \\ 5019 & \text { Calcite in vugs } \\ 5107 & \text { Calcite in vug about } 2 \text { in. diameter } \\ 5116 & \text { Calcite in tight fracture } \\ 5308-5318 & \text { Calcite in vugs and fractures } \\ 5327-5330.5 & \text { Calcite in vugs and fractures } \\ 5418 & \text { Thin calcite coatings on fractures } \\ 5432-5433 & \text { Calcite filling tight anastomosing fractures } \\ 5438-5440 & \text { Calcite filling tight anastomosing fractures } \\ 5460-5462 & \text { Calcite filling tight anastomosing fractures } \\ 5473-5475 & \text { Calcite in vugs and fractures }\end{array}$


Depth (ft)

$5631-5637$

$5682-5686$

5696

5747-5750

5757

5765-5780

5864-5865

5879-5885

$37-52$

57

139

165

182.5-207

223-237. 5

240-241

248

$260-263$

268
Occurrence

Calcite filling openings and irregular tight fractures

Calcite filling irregular fractures

Calcite filling irregular fractures

Calcite filling voids and fractures

Calcite filling vóids and fractures

Calcite filling tight fractures

Calcite in large voids

Calcite in fractures and voids

USW GU-3

(No core 0 to $31 \mathrm{ft}$ )

Calcite-coated lithophysae

Calcite in cavity and fractures

Thin calcite coating on fault

Calcite in lithophysal cavity

Thin calcite coatings on irregular fractures

Minor calcite on fractures

Calcite on fracture and in cavity

Calcite coatings on cavities

Calcite in broken zone

Calcite in 1ithophysae and coating fractures

Note: Nearly every opening in the Tiva Canyon Member above this depth has a little calcite.
$448-449$
$470-472$
479.5
499
521
545.5
548.5
562
636
1121
1709.5
2206.5
2465

Minor calcite in broken zone Minor calcite in broken zone Calcite in irregular fracture Calcite-coated fracture

Calcite in cavities

Calcite in cavities

Calcite in cavities

Calcite in cavities

Calcite in lithophysal cavity

Calcite in irregular opening

Calcite-coated openings

Calcite(?) in lithophysae

Thin calcite coatings on two low-angle fractures 
USW G-3

(Concluded)

Depth (ft)

\section{1}

2931.5-2939.5

2947

2955-2957

2962-2966

2980.5

2981.5

2997

3009-3012

3022.

3025-3030

$3077-3080$

$3082-3084$

3107

$3236-3241$

$3244.5-3251$

$3290-3292$

4316-4318

4331.5

4347

$4365-4370$

4403-4405

4406-4408

4416-4416.5

4420.5

4540

4619.5

$4729-4732.5$

4778

4818

4989

5019.5
Occurrence

Calcite-coated small fault

Calcite-coated irregular fractures

Calcite coating void along small fault

Calcite-coated irregular fracture

Calcite-coated irregular fracture

Calcite in fracture

Calcite in fracture

Calcite-coated fracture

Calcite-coated small fault and opening with $3 / 8$ in. calcite

Calcite-coated fracture

Calcite-coated fracture with voids up to $3 / 16$ in. partly filled with calcite

Calcite-filled fracture

Calcite-filled fracture

Minor calcite in fracture

Minor calcite in partially open irregular fractures

Minor calcite in partially open irregular fractures

Minor calcite coating small sault

Calcite-filled tight fracture

Calcite-filled irregular fracture

Calcite-filled fractures

Calite-fille fricture's

Calcite-filled fractures

Calcite-filled fractures as much as $3 / 8 \mathrm{in}$. wide

Calcite-filled fractures as much as $3 / 8$ in. wide

Calcite in tight irregular fructure

Minor calcite in small ti ht fault

Minor calcite in ault

Calcite in tight fracture

Minor calcite in small fault

Calcite-filled small faul.

Irregular thin calcite vein

Irregular thin calcite vein

USW G-4

(No core 0 to $41 \mathrm{ft}$ )

Occurrence

Calcite on fracture

$1 / 8$ in.-thick calcite on fracture 
$, \ldots, \ldots, \ldots, \ldots, \ldots, \ldots$
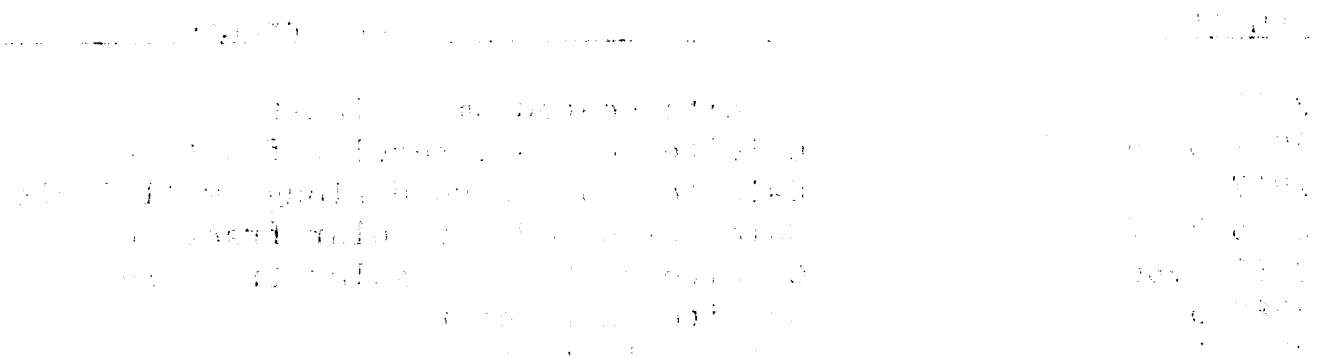

APPENDIX C

-38 - 


\title{
INFORMATION FROM THE REFERENCE INFORMATION BASE
}

USED IN THIS REPORT

This report contains no information from the Reference Information Base.

$$
\begin{gathered}
\text { Candidate Information } \\
\text { for the } \\
\text { Reference Information Base }
\end{gathered}
$$

This report contains no candidate information for the Reference Information Base.

\author{
Candidate Information \\ for the
}

Site \& Engineering Properties Data Base

This report contains no candidate information for the site and Engineering Properties Data Base. 


\section{YUCCA MOUNTAIN SITE CHARACTERIZATION PROJECT}

\section{DISTRIBUTION LIST}

J. W. Barlett (RW-1)

Director

OCRWM

US Department of Energy

1000 Independence Avenue SW

Washington, DC 20585

1 F. G. Peters (RW-2)

Deputy Director

OCRWM

US Department of Energy

1000 Independence Avenue SW

Washington, DC 20585

1 T. H. Isaacs (RW-4)

Office of Strategic Planning and International Programs

OCRWM

US Department of Energy

1000 Independence Avenue SW

Washington, DC 20585

1 J. D. Saltzman (RW-5)

Office of External Relations

OCRWM

US Department of Energy

1000 Independence Avenue SW

Washington, DC 20585

1 Samuel Rousso (RW-10)

Office of Program and Resource

Management

OCRWM

US Department of Energy

1000 Independence Avenue SW

Washington, DC 20585
1 J. C. Bresee (RW-10)

OCRWM

US Department of Energy

1000 Independence Avenue SW

Washington, DC 20585

1 C. P. Gertz (RW-20)

Office of Geologic Disposal

OCRWM

US Department of Energy

1000 Independence Avenue, SW

Washington, DC 20585

1 S. J. Brocoum (RW-22)

Analysis and Verification Division

OCRWM

US Department of Energy

1000 Independence Avenue SW

Washington, DC 2585

1 J. Roberts, Acting Associate

Director (RW-30)

Office of Systems and Compliance

OCRWM

US Department of Energy 1000 Independence Avenue, SW Washington, DC 20585

1 J. Roberts (RW-33)

Dirctor, Regulatory Complaince

Division

OCRWM

US Department of Energy

1000 Independence Avenue, SW

Washington, DC 20585 
1 G. J. Parker (RW-332)

OCRWM

US Department of Energy

1000 Independence Avenue, SW

Washington, DC 20585

1 R. A. Milner (RW-40)

Office of Storage and

Transporation

OCRWM

US Department of Energy

1000 Independence Avenue, SW

Washington, DC 20585

1 S. Rousso, Associate Director (RW-50)

Office of Contract Business

Management

OCRWM

US Department of Energy

1000 Independence Avenue, SW

Washington, DC 20585

1 T. Wood (RW-52)

Director, M\&O Management

Division

OCRWM

US Department of Energy

1000 Independence Avenue, SW

Washington, DC 20585

4 Victoria F. Reich, Librarian

Nuclear Waste Technical Review

Board

1100 Wilson Blvd, Suite 910

Arlington, VA 22209

$5 \quad$ C.P. Gertz, Project Manager

Yucca Mountain Site

Characterization Project Office

US Department of Energy

P.O. Box 98608--MS 523

Las Vegas, NV 89193-8608
1 C. L. West, Director

Office of External Affairs

DOE Nevada Field Office

US Department of Energy

P.O. Box 98518

Las Vegas, NV 89193-8518

12 Technical Information Officer

DOE Nevada Field Office

US Department of Energy

P.O. Box 98518

Las Vegas, NV 89193-8518

1 P. K. Fitzsimmons, Technical

Advisor

Office of Assistant Manager for

Environmental Safety and

Health

DOE Nevada Field Office

US Department of Energy

P.O. Box 98518

Las Vegas, NV 89193-8518

1 D. R. Elle, Director

Environmental Protection

Division

DOE Nevada Field Office

US Department of Energy

P.O. Box 98518

Las Vegas, NV 89193-8518

1 Repository Licensing \& Quality Assurance

Project Directorate

Division of Waste Management

US NRC

Washington, DC 20555

1 Senior Project Manager for Yucca

Mountain

Repository Project Branch

Division of Waste Management

US NRC

Washington, DC 20555 
$1 \quad$ NRC Document Control Desk

Division of Waste Management

US NRC

Washington, DC 20555

$1 \quad$ Philip S. Justus

NRC Site Representive

301 E Stewart Avenue, Room 203

Las Vegas, NV 89101

$1 \quad$ E.P. Binnall

Field Systems Group Leader

Building 50B/4235

Lawrence Berke!ey Laboratory

Berkeley, CA 94720

1 Center for Nuclear Waste

Regulatory Analyses

6220 Culebra Road

Drawer 28510

San Antonio, TX 78284

3 W. L. Clarke

Technical Project Officer - YMP

Attn: YMP/LRC

Lawrence Livermore National

Laboratory

P.O. Box 5514

Livermore, CA 94551

1 J. A. Blink

Deputy Project Leader

Lawrence Livermore National

Laboratory

101 Convention Center Drive

Suite 820, MS 527

Las Vegas, NV 89109

4 J. A. Canepa

Technical Project Officer - YMP

N-5, Mail Stop J521

Los Alamos National Laboratory

P.O. Box 1663

Los Alamos, NM 87545
H. N. Kalia

Exploratory Shaft Test Manager

Los Alamos National Laboratory

Mail Stop 527

101 Convention Center Dr., \#820

Las Vegas, NV 89101

$1 \quad$ N. Z. Elkins

Deputy Technical Project Officer

Los Alamos National Laboratory

Mail Stop 527

101 Convention Center Dr., \#820

Las Vegas, NV 89101

5 L. E. Shephard

Technical Project Officer - YMP

Sandia National Laboratories

Organization 6302

P.O. Box 5800

Albuquerque, NM 87185

1 J. F. Devine

Asst Director of Engineering

Geology

US Geological Survey

106 National Center

12201 Sunrise Valley Drive

Reston, VA 22092

$1 \quad$ L. R. Hayes

Technical Project Officer

Yucca Mountain Project Branch

MS 425

US Geological Survey

P.O. Box 25046

Denver, CO 80225

1 V. R. Schneider

Asst. Chief Hydrologist--MS 414

Office of Program Coordination and Technical Support

US Geological Survey 12201 Sunrise Valley Drive

Reston, VA 22092 
J. S. Stuckless

Geologic Division Coordinator MS 913

Yucca Mountain Project

US Geological Survey

P.O. Box 25046

Denver, CO 80225

1 D. H. Appel, Chief

Hydrologic Investigations Program

MS 421

US Geological Survey

P.O. Box 25046

Denver, CO 80225

1 E. J. Helley

Branch of Western Regional Geology

MS 427

US Geological Survey

345 Middlefield Road

Menlo Park, CA 94025

1 R. W. Craig, Chief

Nevada Operations Office

US Geological Survey

101 Convention Center Drive

Suite 860, MS 509

Las Vegas, NV 89109

1 D. Zesiger

US Geological Survey

101 Conventional Center Drive

Suite 860, MS 509

Las Vegas, NV 89109

1 G. L. Ducret, Associate Chief

Yucca Mountain Project Division

US Geological Survey

P.O. Box 25046

421 Federal Center

Denver, CO 80225
1

A. L. Flint

US Geological Survey

MS 721

P.O. Box 327

Mercury, NV 89023

1 D. A. Beck

Water Resources Division, USGS 6770 S Paradise Road Las Vegas, NV 89119

1 P. A. Glancy

US Geological Survey

Federal Building, Room 224

Carson City, NV 89701

1 Sherman S.C. Wu

Branch of Astrogeology

US Geological Survey 2255 N Gemini Drive

Flagstaff, AZ 86001

1 J. H. Sass

Branch of Tectonophysics

US Geological Survey

2255 N Gemini Drive

Flagstaff, AZ 86001

1 DeWayne Campbell

Technical Project Officer - YMP

US Bureau of Reclamation

Code D-3790

P.O. Box 25007

Denver, CO 80225

1 J. M. LaMonaca

Records Specialist

US Geological Survey

421 Federal Center

P.O. Box 25046

Denver, CO 80225

1 W. R. Keefer - USGS

913 Federal Center

P.O. Box 25046

Denver, CO 80225 
M. D. Voegele

Technical Project Officer - YMP

SAIC

101 Convention Center Drive

Suite 407

Las Vegas, NV 89109

$2 \quad$ L. D. Foust

Nevada Site Manager

TRW Environmental Safety

Systems

101 Convention Center Drive

Suite 540, MS 423

Las Vegas, NV 89109

1 C. E. Ezra

YMP Support Office Manager

EG\&G Energy Measurements Inc

MS V-02

P.O. Box 1912

Las Vegas, NV 89125

1 E. L. Snow, Program Manager

Roy F. Weston Inc

955 L'Enfant Plaza SW

Washington, DC 20024

1 Technical Information Center

Roy F. Weston Inc

955 L'Enfant Plaza SW

Washington, DC 20024

1 D. Hedges, Vice President, QA

Roy F. Weston Inc

4425 Spring Mountain Road

Suite 300

Las Vegas, NV 89102

1 D. L. Fraser, General Manager

Reynolds Electrical \&

Engineering $\mathrm{Co}$, Inc

MS 408

P.O. Box 98521

Las Vegas, NV 89193-8521
1 B. W. Colston, President and

General Manager

Las Vegas Branch

Raytheon Services Nevada

MS 416

P.O. Box 95487

Las Vegas, NV 89193-5487

$1 \quad$ R. L. Bullock

Technical Project Officer - YMP

Raytheon Services Nevada

Suite P-250, MS 403

101 Convention Center Drive

Las Vegas, NV 89109

1 Paul Eslinger, Manager

PASS Program

Pacific Northwest Laboratories

P.O. Box 999

Richland, WAS 99352

1 A. T. Tamura

Science and Technology Division

Office of Scientific and Technical Information

US Department of Energy

P.O. Box 62

Oak Ridge, TN 37831

1 Carlos G. Bell Jr

Professor of Civil Engineering

Civil and Mechanical Engineering Department

University of Nevada, Las Vegas

4505 S Maryland Parkway

Las Vegas, NV 89154

1 P. J. Weeden, Acting Director

Nuclear Radiation Assessment

Division

US EPA

Environmental Monitoring

System! Lab

P.O. Box 93478

Las Vegas, NV 89193-3478 
$1 \quad$ ONWI Library

Batielle Columbus Laboratory

Office of Nuclear Waste Isolation

505 King Avenue

Columbus, OH 43201

1 T. Hay, Executive Assistant

Office of the Governor

State of Nevada

Capitol Complex

Carson City, NV 89710

$3 \quad$ R. R. Loux

Executive Director

Agency for Nuclear Projects

State of Nevada

Evergreen Center, Suite 252

1802 N. Carson Street

Carson City, NV 89710

1 C. H. Johnson

Technical Program Manager

Agency for Nuclear Projects

State of Nevada

Evergreen Center, Suite 252

1802 N. Carson Street

Carson City, NV 89710

1 John Fordham

Water Resources Center

Desert Research Institute

P.O. Box 60220

Reno, NV 89506

1 David Rhode

Desert Research Institute

P.O. Box 60220

Reno, NV 89506

1 Eric Anderson

Mountain West Research-

Southwest Inc

2901 N Central Avenue \#1000

Phoenix, AZ 85012-2730
The Honorable Cyril Schank

Chairman

Churchill County Board of

Commissioners

190 W First Street

Fallon, NV 89406

1 Dennis Bechtel, Coordinator

Nuclear Waste Division

Clark County Department of Comprehensive Planning

301 E Clark Avenue, Suite 570

Las Vegas, NV 89101

1 Juanita D. Hayes

Nuclear Waste Repository

Oversight Program

Esmeralda County

P.O. Box 490

Goldfield, NV 89013

1 Yucca Mountain Information Office

Eureka County

P.O. Box 714

Eureka, NV 89316

1 Brad Mettam

Inyo County Yucca Mountain

Repository Assessment Office

Drawer L

Independence, CA 93526

1 The Honorable Gloria Derby

Chairman

Lander County Board of

Commissioners

315 South Humbolt

Battle Mountain, NV 89820

1 The Honorable Edward E. Wright

Chairman

Lincoln County Board of

Commissioners

P.O. Box 90

Pioche, NV 89043 
1 Vernon E. Poe

Office of Nuclear Projects

Mineral County

P.O. Box 1026

Hawthorne, NV 89415

1 The Honorable Barbara J. Raper

Chairman

Nye County Board of Commissioners

P.O. Box 1240

Pahrump, NV 89041

$1 \quad$ Planning Department

Nye County

P.O. Box 153

Tonopah, NV 89049

$1 \quad$ Florindo Mariani

White Pine County Nuclear

Waste Project Office

457 Fifth Street

Ely, NV 89301

5 Judy Foremaster

City of Caliente Nuclear Waste

Project Office

P.O. Box 158

Caliente, NV 89008

1 Jason Pitts

Lincoln County Nuclear Waste Project Office

Lincoln County Courthouse

Pioche, NV 89043

1 Economic Development Dept.

City of Las Vegas

400 E. Stewart Avenue

Las Vegas, NV 89101

1 Commmunity Planning and

Development

City of North Las Vegas

P.O. Box 4086

North Las Vegas, NV 89030
1 Community Development and

Planning

City of Boulder City

P.O. Box 61350

Boulder City, NV 89006

1 Commission of the European

Communities

200 Rue de la Loi

B-1049 Brussells

BELGIUM

2 M. J. Dorsey, Librarian

YMP Research and Study Center

Reynolds Electrical \&

Engineering $\mathrm{Co}$ Inc

MS 407

P.O. Box 98521

Las Vegas, NV 89193-8521

1 Amy Anderson

Argonne National Laboratory

Building 362

9700 S Cass AVenue

Argonne, IL 60439

1 Steve Bradhurst

P.O. Box 1510

Reno, NV 89505

1 Michael L. Baughman

35 Clark Road

Fiskdale, MA 01518

$1 \quad$ Glenn Van Roekel

Director of Community

Development

City of Caliente

P.O. Box 158

Caliente, NV 89008

1 Ray Williams, Jr

P.O. Box 10

Austin, NV 89310 
$1 \quad$ R. F. Pritchett

Technical Project Officer - YMP

Reynolds Electrical \&

Engineering Co Inc

MS 408

P.O. Box 98521

Las Vegas, NV 89193-8521

1 Charles Thistlethwaite, AICP

Associate $\mathbf{P}_{4}$ :nner

Inyo County Planning Department

Drawer L

Independence, CA 93526

$1 \quad$ Les Bradshaw

Nye County District Attorney

P.O. Box 593

Tonopah, NV 89049

1 Dr. Moses Karakouzian

1751 E Reno \# 125

Las Vegas, NV 89119

$16300 \quad$ D.E. Miller

$1 \quad 6302 \quad$ L.E. Shephard

16304 J.T. Holmes

16312 F.W. Bingham

$16313 \quad$ L.S. Costin

26318 G.M. Gerstner-Miller for 100/1232842/SAND91-7037/NQ

26318 G.M. Gerstner-Miller for DRMS file

$1 \quad 6319 \quad$ R.R. Richards

$16115 \quad$ P.J. Hommert, Acting

206341 WMT Library

$16410 \quad$ D.A. Dahlgren

$5 \quad 7141 \quad$ Technical Library

$17151 \quad$ Technical Publications

10 7613-2 Document Processing for DOE/OSTI

1 8523-2 Central Technical Files

*U.S. GOVERNMENT PRINTING OFFICE: 1993-774-038/64020

$$
\text { Dist. }-8
$$



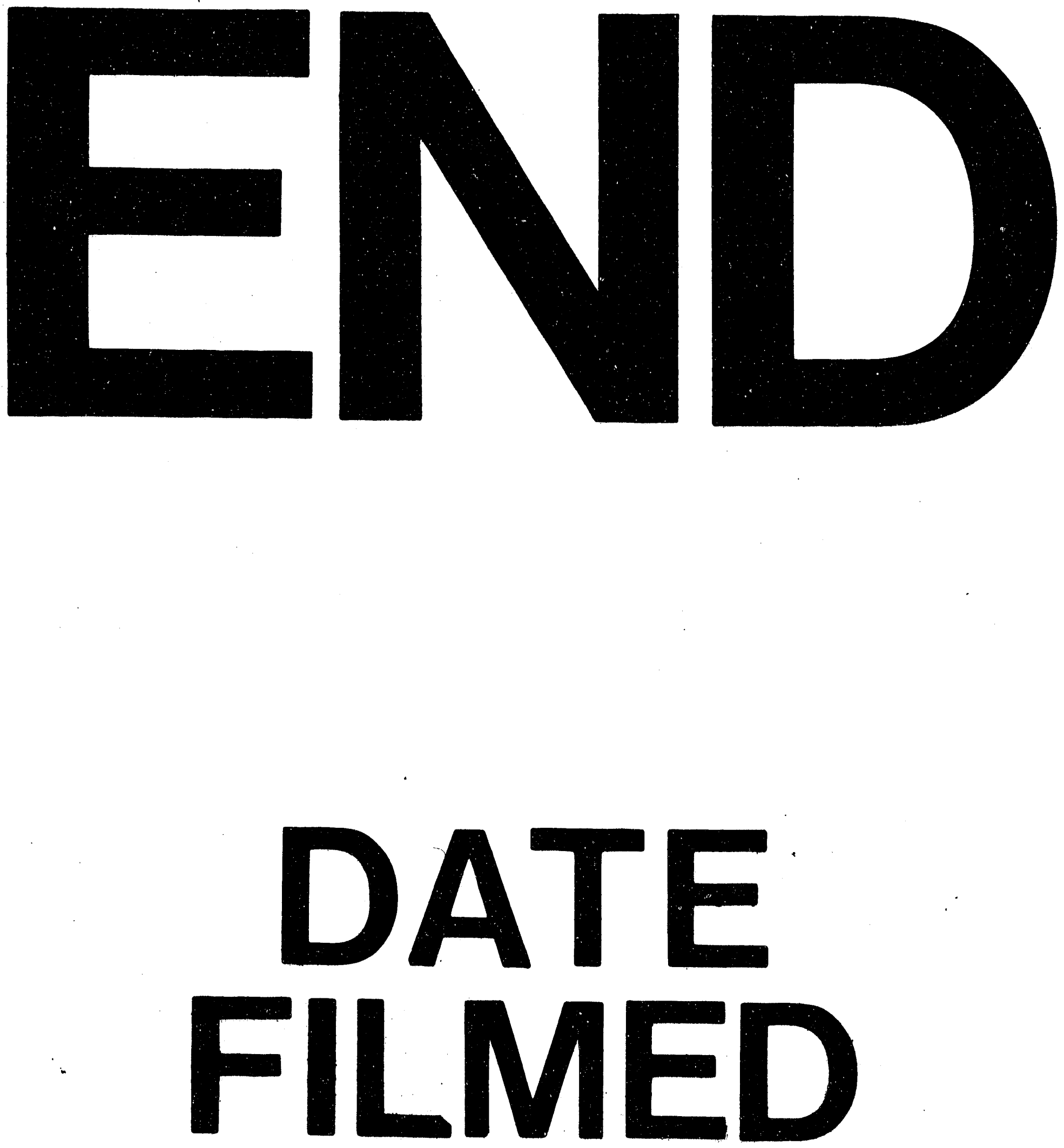

1

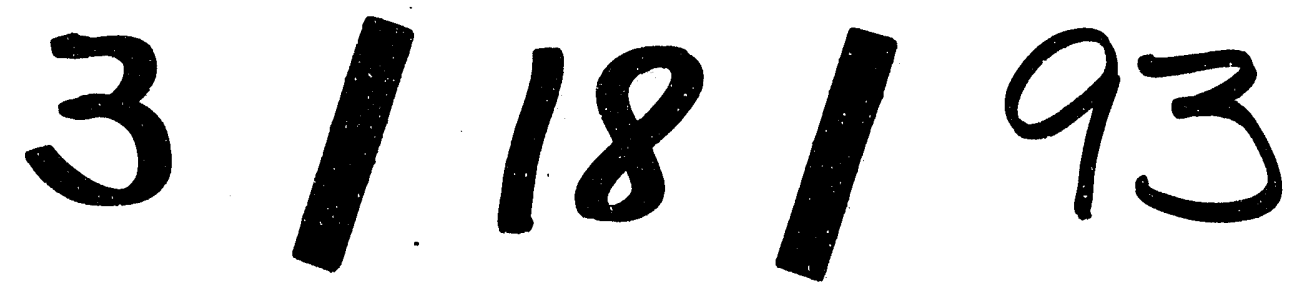


